\title{
APUNTES SOBRE LOS CONTRATOS ATÍPICOS O INNOMINADOS
}

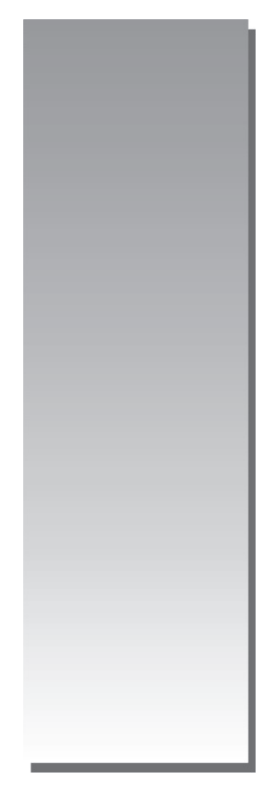

\author{
Máximo Ugarte Vega-Centeno (") \\ E-mail:mugartev@yahoo.com
}

\begin{abstract}
RESUMEN
Los contratos que tienen por objeto bienes intelectuales constituyen, regularmente, contratos innominados o atípicos. Ello significa que la mayoría de estos contratos no están expresamente regulados por la ley. Sin embargo, como todo contrato, están regidos por los principios generales que rigen en materia contractual.

Ahora bien, uno de estos principios generales que rigen los contratos es el principio de autonomía de la voluntad. Este principio reviste gran relevancia dentro de la Teoría General de los Contratos, y en materia de contratos de Propiedad Intelectual su importancia es claramente perceptible, ya que una de las consecuencias más importantes de este principio consiste en la posibilidad de que los particulares celebren convenciones de cualquier tipo, aún no reglamentadas expresamente por la ley. Es así como sirve de fundamento para la existencia de contratos innominados, como los contratos de franquicia, factoring, know how y leasing o los contratos de espectáculo e informáticos.
\end{abstract}

Palabras clave: Contratos atípicos o innominados.

\begin{abstract}
The contracts that consider object intellectual goods constitute, regularly, nameless or atypical contracts. It signifies that the majority of these contracts are not explicitly regular by the law. Nevertheless, as every contract, they are governed by the general principles that govern in contractual matter.

Now well, one of these general principles that govern the contracts is the principle of autonomy of the will. This principle covers great importance inside the General Theory of the Contracts, and in Copyright contracts matter its importance is clearly perceptible, since one of the most important consequences of this principle consists of the possibility that the individuals celebrate conventions of any type, not yet regulated explicitly by the law. It is as well as serves of base for the existence of nameless contracts, like the contracts of franchise, factoring, know how and leasing or the contracts of spectacle and data processing.
\end{abstract}

Keywords: Nameless or atypical contracts.

* Abogado, Magíster en Estudios Europeos por la Universidad Autónoma de Barcelona (España). Doctor en Estudios Internacionales por la Universidad de Córdoba (España). 


\section{INTRODUCCIÓN}

El mercado y el comercio se han visto en la necesidad de buscar alternativas en una economía globalizada y de grandes transformaciones que les posibiliten desarrollarse de manera competitiva, rápida y ágil. Por este motivo, las empresas han superado los contratos ortodoxos que muchas veces están desfasados de las necesidades económicas, financieras y jurídicas actuales, y se han creado nuevas modalidades de contratación conocidas como Contratos Innominados en la búsqueda de ser más competitivos, ya que hoy en día estamos inmersos en una economía de mercado globalizada.

En nuestro país los contratos de factoring, franquicia, know how, fideicomiso, joint venture, underwriting y otros contratos innominados no se encuentran expresamente regulados por la ley y no hace mucho tiempo que se vienen utilizando en otras regiones como América del Norte, Europa y Asia. En ese sentido, desarrollaremos estos contratos denominados atípicos, porque no poseen una regulación legal propia, sino basada en la doctrina y la legislación comparada, pese a que son muy importantes en las transacciones comerciales.

Veamos una breve descripción de cada contrato innominado. La conveniencia de una empresa de movilizar con rapidez su cartera y la circunstancia de contar con un intermediario que conozca profundamente el mercado y las condiciones financieras de los deudores, explican la importancia y el atractivo del factoring.

El contrato de fideicomiso puede llevar al desarrollo de proyectos de gran envergadura, ya que con él se consigue un adecuado manejo de los recursos.

El rápido crecimiento de las franquicias representa el incremento de dos tendencias: la prisa de los personas por llegar a ser sus propios jefes y la necesidad de las compañías de encontrar formas más eficientes y baratas de expandirse. La Franquicia, considerada como estrategia de expansión, conlleva a sus partes integrantes al éxito.

En cambio, los contratos de know how son el resultado de los avances industriales y tecnológicos y, debido a la rapidez de los avances, no es muy práctico utilizar la modalidad de patentes. Los cambios advertidos fundamentalmente en los ámbitos de la tecnología y la informática producen un elevado envejecimiento de los bienes de capital convertidos en obsoletos no por el normal desgaste de su uso, sino porque son desplazados por otros bienes más sofisticados; es por ello que encontramos máquinas que quedan anticuadas antes de ser puestas en servicio. En este ambiente social y económico surge el leasing y se inserta en el mercado financiero como una técnica de financiamiento de la empresa que es complementaria a las tradicionales.

\section{OBJETIVOS}

Por la extensión y compleja multiplicidad de estos contratos atípicos o innominados, nos hemos visto en la necesidad de tomar en consideración aquellos contratos que más se utilizan en nuestra realidad jurídica y socio-económica, pensando fundamentalmente en los estudiantes de pregrado así como a los participantes de las Maestrías y Doctorados de la Unidad de Postgrado de la Facultad de Ciencias Administrativas de la Universidad Nacional Mayor de San Marcos.

El objetivo es que este trabajo sea de divulgación y sirva de consulta en las asignaturas de formación y capacitación profesional de los estudiantes de pre y postgrado. Para ello, el presente trabajo será publicado en la edición $\mathrm{N} .^{\circ} 25$ y en la edición N. ${ }^{\circ} 26$ de la Revista Gestión en el Tercer Milenio. En la primera parte (edición N. ${ }^{\circ} 25$ ) desarrollaremos los contratos atípicos e innominados como el factoring, franquicia, know how, leasing, y los contratos de espectáculos e informáticos; y la segunda parte estará dedicada a los contratos empresariales como fideicomiso, joint venture, underwriting y otros contratos de uso frecuente.

\section{ASPECTOS GENERALES SOBRE LA DEFINICIÓN DE LOS CONTRATOS INNOMINADOS}

Los contratos atípicos van tomando relevancia, con mayor énfasis en la contratación comercial, financiera y jurídica, como consecuencia de las relaciones económicas comerciales en el mundo globalizado ${ }^{1}$ y debido al proceso de inserción que viene teniendo el Perú. Estos contratos se denominan atípicos por no estar legislados en nuestro ordenamiento jurídico aunque se han ido incorporando de manera aún limitada por los principios de licitud y buena fe que tienen las relaciones contractuales regidas por las reglas de autonomía de la voluntad que las partes contratantes implementan para enfrentar y mejorar su

1 Maguiña Flores, Raúl. (2003), pp. 53. 
productividad y competitividad, en el caso de las empresas $^{2}$. En palabras de Leyva Saavedra:

Esta nueva civilización ha consagrado el principio general de la libre competencia y, paulatinamente, ha ido suprimiendo las regulaciones que coartaban una de las manifestaciones más características de la autonomía de la voluntad, la libertad contractual, ocasionando con ello la multiplicación de los contratos atípicos que, del campo estricto del intercambio de bienes, poco a poco han ido trasladando el centro del sistema económico y de la contratación al campo de la prestación de los servicios ${ }^{3}$.

Es allí donde surge y se desarrollan los diferentes contratos. En su mayoría, los contratos que tienen por objeto bienes intelectuales constituyen, regularmente, contratos innominados o atípicos; sin embargo, como todo contrato, están regidos por los principios generales que rigen en materia contractual.

En esa orientación, uno de estos principios generales que rigen los contratos es el principio de autonomía de la voluntad. Este principio reviste gran relevancia dentro de la Teoría General de los Contratos y, en materia de contratos de Propiedad Intelectual su importancia es claramente perceptible, ya que una de las consecuencias más importantes de este principio consiste en la posibilidad de que los particulares celebren acuerdos de cualquier tipo, aunque no estén expresamente reglamentados por la ley. Es así como sirve de fundamento para la existencia de los contratos innominados, como los contratos de transferencia de tecnología o los contratos de franquicia.

Pero este principio no se reduce únicamente a permitir la celebración de contratos no tipificados en la ley, sino que sus efectos se extienden hasta la libertad que tienen los particulares para la determinación del contenido de los contratos, es decir, la libertad para el establecimiento de las obligaciones que de estos derivan. Es en este sentido en el que revisten mayor relevancia las limitaciones que se establecen al principio de autonomía de la voluntad, pues las mismas están referidas más al contenido de las obligaciones contractuales que a la tipología del contrato que les da nacimiento ${ }^{4}$.
Los contratos innominados han sido extensamente tratados por la doctrina y la jurisprudencia internacional y nacional; inclusive un sector de la doctrina da una definición negativa de los contratos innominados ${ }^{5}$ sosteniendo que, aunque están mencionados en la ley, dichos contratos están desprovistos de una normativa específica, a menos que la mención del contrato se haga por ley; en tal caso se pueden incluir estos contratos por uso de remisión de la disciplina jurídica aplicable. Sin embargo, estos contratos han seguido desarrollándose fundamentalmente por:

- La influencia del derecho anglosajón con nuevas formas de contratación que, por su sentido práctico y eficaz, se introducen primero en Europa y posteriormente en América Latina.

- Los avances tecnológicos que exigen nuevos usos.

- El fenómeno del comercio exterior y la globalización.

- Los intercambios entre Estados que se vieron obligados a aceptar nuevas formas de relaciones económicas poco utilizadas en el ámbito nacional.

- El desarrollo de las sociedades mercantiles con las exigencias que ello reporta: programación a larga distancia, contratos para intercambio o compra de tecnología, utilización de patentes.

- Los vacíos que tiene nuestro sistema jurídico civil respecto a estos contratos.

Entonces, podemos decir que estos contratos que no son regulados por la ley de un modo específico y, en consecuencia, no tienen una denominación, en tal virtud quedan sujetos a lo estipulado en el Código Civil, Libro VII, Fuentes de la Obligaciones, en virtud de lo dispuesto por el artículo 1353 que establece que:

todos los contratos de derecho privado, inclusive los innominados quedan sometidos a las reglas generales contenidas en el Libro VII, salvo en cuanto resulten incompatibles con las reglas particulares de cada contrato ${ }^{6}$.

En términos generales, los contratos atípicos son aquellos que no estando definidos por la legislación positiva están reconocidos por la realidad social, económica y jurídica, y en ocasiones por leyes especiales, basándose en la libertad

2 Porter, Michael E. (1991), pp. 1051.

3 Leyva Saavedra, José. (2001), pp. 7 y 8.

4 Villacorta Cavero, Armando. (2001).

5 Alterine Atilio y López Cabana, Roberto (1989).

6 Véase Código Civil. 
contractual y en la autonomía de la voluntad, rigiéndose por su afinidad con otros contratos típicos, por los principios generales de las obligaciones y contratos, y subsidiariamente por los principios generales del Derecho.

Como los contratos innominados se basan en el principio de libertad contractual, los contratantes pueden establecer los pactos, cláusulas, y condiciones que tengan por conveniente, siempre que no sean contrarios a las leyes, a la moral o al orden público. Las obligaciones que nacen de los contratos tienen fuerza de ley entre las partes contratantes y deben cumplirse según el tenor de las mismas.

\section{Diferencia entre los contratos nominados $y$ los innominados}

Entendida la figura del contrato nominado como el que está expresamente previsto y regulado por el ordenamiento jurídico positivo, tiene sus antecedentes en el Derecho Romano clásico, donde no solo se conocía una figura general del contrato sino contratos singulares; es decir, cada uno con su propio nombre.

Los códigos tradicionales recogieron este concepto al distinguir entre contratos que tienen una denominación propia de los que no la tienen, por ello estarían dentro de los contratos innominados aquellos creados por las partes sin base en el derecho positivo para regular una situación específica que pueda ser única y pudiera no volver a repetirse. Ahora, si las necesidades del mercado hicieran que un contrato innominado se repita, progresivamente se va reconociendo y adquiriendo modalidades y funciones propias con cierta permanencia, convirtiéndose gradualmente en un contrato nominado ${ }^{7}$.

\section{Clasificación}

Encontramos una multiplicidad en la clasificación de estos contratos atípicos o innominados y, como ya mencionamos anteriormente, los priorizaremos de acuerdo a nuestros objetivos planteados en el presente trabajo y según la importancia que tienen todos estos contratos. Así organizaremos el desarrollo de estos apuntes tomando en consideración el orden alfabético y basándonos en algunas notas previas, definición, naturaleza jurídica, características, sujetos del contrato, así como ventajas y desventajas de estos contratos.

\section{CONTRATO DE FACTORING}

\section{Notas previas}

La doctrina no se pone de acuerdo en relación al origen etimológico del vocablo factoring. Así, algunos autores afirman que esta expresión proviene de los fenicios, específicamente del término factus, que significa "el que hace algo". Para otros autores, la expresión factoring proviene del término inglés factor más no del vocablo "factura", acotando que el factoring se traduce al español como "Factoraje". Sin embargo, semánticamente el término aludido equivale al empleo y encargo que efectúa un determinado comerciante a fin de que el factor pueda obrar en nombre y por cuenta de éste.

Los inicios del contrato de factoring siguen generando debate en la doctrina nacional y comparada. Rebuscando en la historia algunos encuentran una primera forma de factoring en la cultura neobabilónica de los Caldeos con la actividad desarrollada por el Shamgallu, agente comercial operante en Caldea hace 4,000 años y que fungía como un comisionista, es decir, una persona que por el pago de una comisión garantizaba a su comitente el pago de los créditos. Otros, por su parte, creen encontrar un indicio de la modalidad del factoring en las costumbres comerciales de los fenicios.

El factoring podemos encontrarlo fundamentalmente en la época de los romanos. En esta orientación se fundamenta que la figura jurídica del factoring no es una creación del derecho moderno ya que fue conocida por los romanos, correspondiendo en sus rasgos más sustanciales a los del institor. En ese sentido, para tener una idea más completa de las distintas teorías acerca del origen del factoring, se encuentra el antecedente más remoto de esta moderna institución contractual en la actividad de los commanditari italianos, que en el medioevo operaban como financiadores y aseguradores de las operaciones comerciales realizadas por los viajeros, tomando parte en las ganancias y en las pérdidas ${ }^{8}$. Luego, la doctrina resalta el origen del negocio jurídico que más tarde conduciría al contrato de factoring, que debemos buscarlo a finales del siglo XIV y comienzos del siguiente en Inglaterra.

La doctrina jurídica y económica muestra consenso en que es Inglaterra, particularmente

7 Villacorta Cavero, Armando (2001). Op. cit.

8 Ascensio, Pedro (1995). 
Londres, la cuna del contrato de factoring. Recuerda Rodgers que la Blackwell Hall, dedicada a la industria de la lana en 1397, es considerada como el lugar de nacimiento del factor comercial. Esta empresa recibía las mercaderías en consignación y las vendía a los comerciantes de la zona con la particularidad que, en ocasiones, adelantaba a los fabricantes el precio de las mercaderías que le habían sido confiadas.

A inicios del siglo XVII, en el propio Londres, se establecieron numerosos factors, llegando algunos de ellos a especializarse en el comercio de algodón, por lo que se les bautizó como los cotton factors. Esta práctica pronto fomentó de manera considerable el comercio británico de exportación, desarrollando el concepto de las confirming houses que, en representación de los compradores extranjeros, garantizaban su crédito y confirmaban los pedidos. Posteriormente, con la expansión, desarrollo y beneficios obtenidos con estas operaciones, los factors financiaron la producción de sus clientes al hacer efectivo el pago inmediato del precio de las mercaderías que debían exportarse algunas semanas después. En este momento, como podemos observar, la función comercial, propia de los factors en sus inicios, cambia y evoluciona hacia funciones de financiamiento empresarial ${ }^{9}$.

Como vemos, el factoring como contrato surgió a consecuencia de las necesidades del tráfico comercial colonial europeo, puesto que los exportadores ingleses - para obviar las posibles complicaciones del transporte de mercaderías por motivos tales como la distancia, el desconocimiento del mercado colonial americano, el cobro respectivo etc.- emplearon los servicios de determinados representantes, quienes se encargaban de comercializar las mercaderías configurándose a su vez en depositarios; ellos eran los denominados factors ${ }^{10}$.

En la década de los sesenta del siglo pasado, esta figura se introduce en Europa con una modalidad más moderna: la presentación por parte de la compañía de factoring de más servicios como el estudio del mercado, contabilidad, información comercial, entre otros. En los años setenta este tipo de contrato se introdujo en España, principalmente en Cataluña, con la constitución de empresas como Internacional
Factor Española SA., Transfactor SA. y Heller Factorings Española SA. ${ }^{11}$. En resumen, como indica Sánchez Bustillo:

el factoring es oriundo de Inglaterra y su denominación proviene del vocablo inglés 'factor', nombre utilizado en ese país para individualizar a los comerciantes que eran enviados a los Estados Unidos para conquistar el mercado norteamericano ${ }^{12}$.

En la actualidad, las empresas nacionales, principalmente las que se dedican a exportar sus productos, tienen en el factoring un apoyo y alternativa de autofinanciamiento diferente a las que ofrece el sistema tradicional de crédito, quitándose de encima la carga administrativa, lo que se valora mucho en estos tiempos de eficiencia y competitividad. El factoring, si se utiliza adecuadamente, permite que las empresas exportadoras puedan dedicarse íntegramente a su actividad habitual, es decir a la producción de bienes a la prestación de servicios, y dejar la cobranza, gestión, administración y contabilización de los créditos a las empresas especializadas en factoring.

La práctica, que es el criterio de la verdad, nos va demostrando que cada vez más empresas recurren a esta modalidad para cumplir sus objetivos y disminuir los costos que les representa constituir un departamento especializado en cobros que, además de un buen servicio al cliente, obtenga un buen resultado frente a esos clientes morosos al momento de pagar los servicios u obras. En estos apuntes pretendemos dar una visión global de lo que significa este instrumento para un mejor uso empresarial.

Al celebrar un contrato de factoring, toda empresa busca obtener una racionalización de su organización, disminuyendo los costos de gestión de carácter administrativo y contable y, de esta manera, asegurar el cobro de sus créditos y obtener una mayor liquidez, ya que tiene la posibilidad de conseguir el importe de los créditos cedidos anticipadamente. En otras palabras, el factoring le facilita las cosas a las empresas pues deja a una empresa especializada la gestión administrativa y financiera relativa a sus relaciones con sus propios clientes, lo que le permite dedicarse a la actividad productiva y comercial.

9 Cogorno, Eduardo. (1979), pp.131 y ss.

10 De Eizaguirre, Jose María. (año), pp. 39 y ss.

11 Chuliá Vicent, Eduardo. (1999), pp. 15.

12 Véase Sánchez Bustillo, Augusto. (2006), p. 31. 
Es importante señalar que, en la práctica, el servicio que más se ha favorecido del desarrollo del factoring en la actividad empresarial es el financiero. Casi siempre esta prestación la realiza la factora que viene estipulada por la orden de los créditos de la empresa factorada; tal orden se concreta mediante el pago anticipado de los créditos efectuados por la primera a esta última, lo que permite una mejora considerable del flujo de caja y, como consecuencia, disminuye las necesidades financieras que surgen en la habitual actividad empresarial ${ }^{13}$.

\section{Algunos apuntes legislativos del factoring en el Perú}

El primer antecedente legislativo del factoring en nuestro país podemos encontrarlo en el Decreto Legislativo $\mathrm{N} .^{\circ} 770$, en los artículos 246 , inciso c) y el artículo 404 , incisos g) y q), que se referían a la capacidad con la que contaban las instituciones bancarias para adquirir y negociar letras de cambio y facturas que provenían de transacciones comerciales. Como en muchos contratos atípicos, la única definición legal existente es de tipo tributario y fiscal, así tenemos la Ley N. ${ }^{\circ} 26702$ (Ley General de Sistema Financiero y del Sistema de Seguros y Orgánica de la Superintendencia de Banca y Seguros), norma que en el artículo 221, inciso 10), así como en el artículo 282, inciso 8) hace alusión al contrato de factoring ${ }^{14}$.

En la actualidad, la normas que regulan el contrato de factoring en nuestro país son la Resolución N. ${ }^{\circ} 1021-98-S B S^{15}$ (Ley del Impuesto General a las
Ventas), el Decreto Legislativo N. ${ }^{\circ} 821$ de 1996 para efectos tributarios, y el Decreto Supremo $\mathrm{N}^{\circ}$ 136-96-EF de 1996 que modifica materias tributarias relativas a operaciones de factoring ${ }^{16}$.

\section{Definición}

El factoring es un contrato relevante que enmarca múltiples definiciones y que ha generado diferentes lecturas en la doctrina nacional y comparada ${ }^{17}$. En lo que sí están de acuerdo la doctrina económica y jurídica es sobre el servicio que brindan las empresas factoras a las factoradas que es el de financiamiento, que en opinión de algunos representa su principal contenido económico. El financiamiento es el que más ha contribuido a su aceptación y desarrollo en el mercado internacional, en ese sentido ponemos a consideración algunas definiciones a criterio nuestro.

Diferentes estudiosos de estos contratos han definido y conceptualizado el factoring, entre estos tenemos a Roca Guillamón que señala que es:

... una actividad de cooperación empresarial que tiene por objeto para el factor, la adquisición en firme a los productores de bienes $o$ presentadores de servicio, de los créditos de que sean titulares contra sus clientes o compradores, garantizando su satisfacción $y$ presentando servicios complementarios de contabilidad, estudio de mercados, investigación de clientela, entre otros, a cambio de una retribución, a lo que puede agregarse una posibilidad de financiación mediante anticipos con devengos de intereses ${ }^{18}$.

13 Ver Borges, Denis (1988).

14 Véase Ley N. ${ }^{\circ} 26702$ del 09 de diciembre de 1996, Ley general del sistema financiero y del Sistema de Seguros y Orgánica de la Superintendencia de Banca y Seguros en su artículo 221: Las empresas podrán realizar las siguientes operaciones y servicios, de acuerdo a lo dispuesto por el Capítulo I del Título IV de esta Sección Segunda. Inciso 10.- Realizar Operaciones de Factoring. Artículo 222. Definiciones. Inciso 8.- Empresa de factoring cuya especialidad consiste en la adquisición de facturas conformadas, títulos valores y en general cualquier valor mobiliario representativo de deuda.

15 La Resolución N. ${ }^{\circ}$ 1021-98-SBS: La Ley General de Sistema Financiero y del Sistema de Seguros y Orgánica de la Superintendencia de Banca y Seguros, Ley . $^{\circ}$ 26702, en adelante Ley General, en los numerales 4 y 10 del artículo 221 establece que las empresas del sistema financiero están facultadas para realizar operaciones de descuento y de factoring; Que, asimismo, el artículo 16 de la Ley General prevé el establecimiento de empresas de factoring como empresas especializadas del sistema financiero cuyo objeto social está definido en el numeral 8 del artículo 282 de la referida disposición legal; Que, en consecuencia, resulta necesario establecer el marco regulatorio de las operaciones de factoring y descuento; así como las normas que deberán observar las empresas de factoring para efectos de su organización y funcionamiento; Estando a lo opinado por las Superintendencias Adjuntas de Banca y de Asesoría Jurídica; y, en uso de las atribuciones conferidas por los numerales 7 y 9 del artículo 349 de la Ley General; RESUELVE: Artículo Primero.- Aprobar el Reglamento de factoring, descuento y empresas de factoring que forma parte integrante de la presente resolución.

16 Véase Resolución N. ${ }^{\circ}$ 1021-98-SBS del 03 de octubre de 1998, Decreto Legislativo N. ${ }^{\circ} 821$ del 23 de abril de 1996 y Decreto Supremo N. ${ }^{\circ}$ 136-96-EF del 31 de diciembre de 1996.

17 Ver al respecto Sánchez Bustillo, Augusto (2006). Op. cit, pp. 27 y ss. Para ver el problema de la definición ver Leyva Saavedra, José (2001), Op.cit., pp. 46-60.

18 Roca Guillamón, Juan (1976), p. 125. 
Otros lo consideran como un contrato mercantil atípico, consensual y sinalagmático mediante el cual una de las partes entrega a la otra denominada factor, toda su documentación de cobro para que ésta la gestione, bien anticipando su importe menos el descuento convenido, o limitándose a su gestión estricta de percibir los importes devengados por terceros, pudiendo realizar el factor otros servicios complementarios.

Diversos autores definen que el factoring es un contrato por el cual una entidad financiera se obliga frente a una empresa a adquirir todos los créditos que se originen normalmente y de manera constante en su negocio por venta de mercaderías, durante un período expresamente convenido, pero pudiendo reservarse las facultades de seleccionar esos créditos y pagar por ellos un precio fijado mediante una proporción establecida sobre los importes y a prestar determinado servicio, quedando los riesgos de cobro a cargo de las entidades financieras.

Otros autores consideran al factoring como una actividad de cooperación empresarial que tiene por objeto, para la entidad financiera denominada factor, la adquisición a sus clientes de los créditos de que sean titulares contra sus compradores y deudores, garantizando su satisfacción y prestando servicios de contabilidad, estudios de mercado, investigación de su clientela, asesoramiento e información. Samuel Linares Bretón (citado por Bravo Melgar ${ }^{19}$ ) define al factoring como el contrato en virtud del cual una entidad financiera se obliga frente a una empresa a adquirirle todos los créditos que se originen normalmente y de una manera constante en su negocio por venta de mercaderías durante un período de tiempo expresamente convenido, pero pudiendo reservarse la facultad de seleccionar esos créditos y abonar por los mismos un precio fijado mediante una proporción establecida sobre su importe y a prestar determinados servicios, quedando los riesgos de la contabilidad a cargo de la entidad financiera. También se afirma que el factoring es un contrato que establece la prestación de una serie de servicios por parte de una entidad financiera o factor a un determinado cliente a quien fundamentalmente le provee de financiación mediante la compra de la cartera de créditos que éste posee y que provienen de sus ventas, además de otros servicios complementarios administrativos o contables.
En nuestro país el factoring radica en la venta de activos líquidos de corto plazo, entre ellos, cuentas por cobrar, letras, créditos y facturas que representen una suma determinada. A través del factoring se contribuye a la minimización de gastos por parte de las empresas, presentándose como una alternativa empresarial de servicios administrativos y financiamiento de capital de trabajo que permite cubrir las acreencias corrientes en el plazo establecido. Mediante este contrato el cedente (cliente) vende o cede créditos comerciales al factor (cesionario) a fin de liberarse de una serie de labores y responsabilidades que desde el momento de la cesión asume el factor y que son conocidas como los servicios principales y complementarios que enmarca el factoring.

Podemos decir entonces que el factoring es la operación por la cual un empresario transmite en exclusiva los créditos que frente a un tercero tiene como consecuencia de su actividad mercantil a un factor, el cual se encargará de la gestión y contabilidad de los créditos, pudiendo asumir los riesgos de la gestión y contabilidad de tales créditos mediante anticipos a favor de su cliente, servicios desarrollados a cambio de una prestación económica que el cliente pagará a favor de su factor.

También se puede definir que el factoring es un contrato mediante el cual una persona titular de determinados valores mobiliarios insolutos, caso de cheques, letras de cambio, facturas conformadas, etc., vende dicho paquete crediticio por un precio convenido a otra persona jurídica denominada factor a fin de que ésta se encargue de efectivizarlos. Ello es conocido como el factoring con financiación; sin embargo, la otra modalidad relevante del factoring se caracteriza por la cesión que efectúa el titular de los créditos insolutos al factor a condición de que éste último se encargue de cobrarlos a cambio de una contraprestación pecuniaria (comisión) que percibirá en su oportunidad; ello es conocido como el factoring sin financiación.

En resumen, se puede decir que el factoring, en la fase más moderna de su evolución, es una forma de negocio que ofrece todo un conjunto de servicios de naturaleza contable, administrativa, financiera y de garantía, que permite a las empresas productoras de bienes o suministradoras de servicios transferir su economía externa a

19 Bravo Melgar, Sidney Alex (2003a), pp. 583 y ss. 
empresas especializadas, así como la gestión y el cobro de los créditos provenientes de su actividad empresarial y, en general, el riesgo de insolvencia de los deudores, gozando -al mismo tiempo- de financiamiento y asistencia en otros sectores. Coincidiendo con muchos autores, con el factoring se da una situación muy especial de colaboración empresarial, pues mientras la factorada produce $\mathrm{y}$ vende, la factora financia y cobra ${ }^{20}$.

\section{Naturaleza jurídica}

En relación a la naturaleza jurídica del contrato de factoring no existe un criterio unánime a nivel jurídico doctrinario ${ }^{21}$, puesto que los diversos especialistas en el tema tratado tienen sus propios criterios dependiendo de la legislación ad hoc de su respectivo país de origen.

Para algunos especialistas en la actualidad el contrato de factoring es un contrato típico, puesto que ya cuenta con una norma propia que intenta regularlo ${ }^{22}$. Asimismo, señalan que es un contrato nominado por contar con un nomen juris y no podemos olvidar que al margen de ser un contrato de derecho privado se trata de un contrato eminentemente mercantil.

En cambio, para otros se trata de un contrato mercantil atípico que no está regulado por la legislación positiva, y agregan además que es un contrato mixto puesto que en su desarrollo intervienen tanto el arrendamiento de servicios (gestión de cobro de documentos de títulos valores, facturas, etc.), como también el descuento de capital, ya que a veces la compañía de factoring anticipa todo o parte de los créditos que recibe.

\section{Características del factoring}

Podemos citar como características del factoring las siguientes:

- Es un contrato principal. Posee autonomía propia y no depende de uno u otros contratos existentes con anterioridad, y puede ir acompañado de contratos accesorios como las garantías personales o reales.
- Es un contrato bilateral (sinalagmático). Existen dos partes contratantes, las cuales enmarcan contraprestaciones (cliente-empresa).

- Es un contrato conmutativo. Las partes contratantes con anticipación pueden prever los resultados del contrato, sabiendo obviamente cuáles son sus derechos, obligaciones y los beneficios de cada una.

- Es un contrato complejo. En virtud a que encierra un conjunto determinado de servicios complementarios.

- Es un contrato típico. Ya que existe una norma propia que lo regula, nos estamos refiriendo a la Resolución N. ${ }^{\circ}$ 1021-98-SBS ${ }^{23}$.

- Es un contrato oneroso. Importa beneficios para ambas partes contratantes y cada una de éstas debe a la otra una prestación gravosa, la cual es valuable en numerario.

- Es un contrato de tracto sucesivo. Como afirma Arias Schreiber en razón al lapso de duración que enmarca, por ende se halla ceñido a todas las figuras jurídicas colaterales como son la lesión, la excesiva onerosidad de la prestación, el incumplimiento del contrato, etc.

- Es un contrato moderno. Aunque hace pocos años que en nuestro país se patentiza este contrato.

\section{Sujetos que intervienen en el contrato de factoring}

El factor puede ser un banco o una empresa especializada de factoring que se encarga de adquirir los créditos por cobrar o facturas de su cliente a pagar el importe o prestarle servicios de contabilidad, administración, entre otros. Como consecuencia por los servicios prestados el factor recibe una prestación, consistente en un porcentaje de los montos de las facturas, así como los intereses devengados por los anticipos al cliente.

En otras palabras, las partes que intervienen en el contrato de factoring son el factor que puede ser un banco, una empresa financiera o una socie-

20 Véase Baylos C., Hermenegildo (1993).

21 Ver Caballero Bustamante. "Revista informativa”. En línea: http://www.caballerobustamante.com.pe/boletin/boletincomercial33. Ver también Téllez Sánchez, Lino; Ferrando Alonso, Leticia; y Peña Domínguez, Misdalia. "Trabajo sobre el Factoring. Legislación y tratamiento contable”. En línea: www.monografias.com/trabajos16/factoring-contable; también Leyva Saavedra, José. "El factoring, un negocio de autofinanciamiento". En línea: http://www.injef.com/revista/empresas/factoring2a.htm

22 Ver Resolución N. ${ }^{\circ}$ 1021-98-SBS, Reglamento de Factoring, Descuento y Empresas de Factoring, del 03 de octubre de 1998. 23 Idem. 
dad especializada ${ }^{24}$, y de otro lado el cliente, que puede ser una persona natural o jurídica, quien es titular de un determinado número de créditos insolutos. El primero será el que se encargue de efectivizarlos. Los deudores del cliente no forman parte del contrato, sin embargo tienen un rol fundamental en el desarrollo del mismo.

En lo concerniente al factor, cabe comentar que se instituye en la entidad que cuenta con recursos financieros y con una infraestructura técnica y contable que le permite manejar la cobranza de los créditos no pagados, investigando para ello la solvencia de los deudores, hasta la cobranza judicial. Los clientes -como ya anteriormente expusimos- pueden ser personas naturales o jurídicas, industriales o comerciantes que en atención al volumen de su cartera conformada por créditos insolutos son presentados al factor.

Respecto a los deudores, su existencia es importante para la celebración del contrato de factoring, puesto que de su capacidad económica y solvencia evaluada y aceptada por el banco y de la satisfacción de sus obligaciones dependerá la continuidad del contrato.

\section{Ventajas y desventajas}

En su mayoría, los autores coinciden en señalar las ventajas y desventajas que el cliente y el factor ${ }^{25}$ asumen con este contrato; entre estas tenemos:

\section{a) Para el cliente}

- La posibilidad de conceder crédito en sus operaciones comerciales, aumentando de ese modo el volumen de las mismas.

- La mayor liquidez que supone el anticipo de fondos que el factor puede efectuar con cargo a los créditos que el cliente le ha cedido.

- El traslado de los costos que supone el mantener una estructura para el otorgamiento de créditos y su cobranza (personal especializado, análisis de los riesgos, etc.).

- El traslado de los riesgos derivados de la concesión de los créditos ante posibles moras e incumplimientos. b) Para la empresa de facturación. Para el factor, que habitualmente es una entidad financiera $o$ un banco, el factoring resulta útil como medio de dispersión del crédito, ya que en lugar de otorgar un préstamo importante a favor de una sola empresa lo que hace en realidad es facilitar créditos de menor importe a favor de muchas; el riesgo, por ende, resulta menor.

\section{Futura regulación normativa del factoring}

La regulación específica de estos contratos se estima que se aprobará en su momento teniendo en consideración identificar el contrato con un nomen juris que podría ser contrato de factoraje, facturación o financiación, diferenciándose en la forma con los criterios doctrinarios expresados anteriormente y orientándose como un contrato de cooperación empresarial dedicado a la adquisición de créditos que se originan en forma constante en un negocio, con la opción exclusiva del factor para seleccionarlos, obligándose a abonar su importe así como a brindar otros servicios que deriven de una mayor eficacia y rentabilidad.

\section{CONTRATO DE FRANQUICIA (FRANCHISING)}

\section{Introducción}

Es la modalidad de contratos conocida también como contrato de colaboración entre diferentes empresas, donde una de ellas (franquiciante) cede y pone a disposición una técnica empresarial y somete al franquiciado un producto de marca que tiene fama y reconocimiento en el mercado. Podemos decir que es la organización e instrumentalización de la concesión o privilegio para poner en marcha un servicio o atención de una cadena de locales iguales y pertenecientes a la misma marca a cambio de pagos de regalías, y que incluye todos los componentes del proceso de comercialización, planeamiento, promoción y publicidad, compras, producción, ventas y análisis de la competencia. La franquicia puede ser por un determinado período. Este sistema de franquicia tiene unas autorizaciones básicas para desarrollarse en las mejores condiciones.

24 En nuestro país estas empresas deben contar con la autorización ad hoc de la Superintendencia de Banca y Seguros, tal como lo dispone el artículo 6 de la Resolución N. ${ }^{\circ} 1021-98$-SBS.

25 Véase Leyva Saavedra, José (2001), op. cit., pp. 245-254, y Bravo Melgar, Sidney Alex (2003a), op. cit., pp. 589-590. 


\section{Notas previas}

El contrato de franquicia, tal como se conoce en la actualidad, es una modalidad casi nueva. Aunque sus antecedentes históricos podemos encontrarlos en la antiguiedad como una forma de prestación de servicios públicos, en el siglo $\mathrm{XX}$ ha sido utilizado por el sector privado como un sistema de mercadotecnia aplicado a bienes y servicios, especialmente en Europa.

El desarrollo del concepto de franquicias se origina en el siglo XII. Sin embargo, existen dos épocas muy señaladas en el desarrollo de las franquicias como sistema comercial (segunda mitad del siglo XX) y de negocios (desde la postguerra hasta la actualidad) ${ }^{26}$.

Originariamente, la palabra franquicia era sinónimo de privilegio. En la Edad Media, en Europa, existían las denominadas Ciudades con Cartas Francas que garantizaban ciertos privilegios a las ciudades y/o ciudadanos. Otros, en cambio, atribuyen su surgimiento a la concesión hecha por la Iglesia Católica a ciertos señores de tierras para que actuaran en su nombre recolectando los impuestos para la misma.

De acuerdo a la doctrina jurídico-económica este contrato surge como franquicia comercial en Estados Unidos en 1850 aproximadamente, cuando la compañía Singer \& Co. o Singer Sewing Machine Company, crea una novedosa forma de distribución y venta para sus máquinas de coser que continúa hasta nuestros días. Es de recordar también que la empresa General Motors adopta el franchising como estrategia de expansión para su red de distribuidores a partir de 1898. Otros autores manifiestan que fue en la década del treinta que Howard Johnson establece la primera franquicia con una cadena de 25 franquiciados aproximadamente, y a partir de la década del cincuenta aparecen las grandes franquicias.

En el ámbito europeo el contrato de franquicia se origina en los hoteles históricos de Nueva Gales del Sur, los que realizaban contratos de franquicia con los cerveceros. Paralelamente, en el continente americano la franquicia se inicia cuando se constituyó el sistema de telégrafo eléctrico que gestionaban varias compañías de ferrocarriles pero que estaba controlado por la Western Unión.

La franquicia moderna tuvo su apogeo en los años cincuenta con el surgimiento de los restaurantes de comida rápida entre los cuales McDonald's fue el primero en recoger un éxito global gracias al sistema de franquicia, camino seguido por muchas empresas de gestión individual.

\section{Definición}

La denominación en el ámbito internacional de este modelo de contratación es conocido por su nombre o designación dada en su país de origen, Estados Unidos, mientras que en el mundo de habla hispana es traducido a idioma castellano como franquicia. Lamentablemente el significado idiomático de esta palabra no expresa el concepto y el contenido del contrato de franchising en su totalidad ${ }^{27}$. A nuestro entender, se le debe denominar franquicia comercial por ser la terminología correcta.

Algunos autores sostienen que la franquicia es un tipo de contrato utilizado en el comercio, por el que una parte llamada franquiciador cede a otra llamada franquiciado la licencia de una marca así como métodos de hacer negocios a cambio de una tarifa periódica o royalty. Una franquicia es un método de negocio donde el propietario de una marca y métodos lo licencia a otro a cambio del pago de una regalía ${ }^{28}$. En otras palabras, es vender el derecho de una marca. Otros simplemente indican que es el derecho otorgado a un comerciante para la distribución y venta de los productos de un fabricante. Otros señalan que viene a ser el acuerdo de venta en el que una compañía (franquiciador) cede los derechos a una persona o compañía (franquiciatario) para proporcionar los productos o servicios del franquiciador en un mercado específico. El franquiciatario se compromete a operar de acuerdo a las normas establecidas por el franquiciador, las cuales normalmente incluyen el uso de sus productos, materiales promocionales y otros servicios de soporte de la compañía ${ }^{29}$.

26 Véase Ascencio, Pedro (1995), op. cit., pp. 65 y 67, y Massanguer, José (1989), p. 69.

27 Sobre franquicias ver Kennedy, David (2002), y Arrubla Páucar, Jaime Alberto (1997).

28 Ver Alonso, Mariano (2003), op. cit. Otros autores también lo definen como negocio que es operado por el dueño (franquiciado) bajo licencia de otra persona (franquiciador), que le da el derecho limitado de usar la marca registrada, planes operacionales confidenciales y de mercadeo, y otras informaciones, para mantenerse dentro de las especificaciones y procedimientos del franquiciador, por un periodo específico de tiempo y dentro de área o localidad específica.

29 Ver Comité Belga de Distribución (1997). 
Otra definición indica que el tiempo durante el cual es válido un acuerdo de licencias puede ir desde cinco años hasta la perpetuidad, aunque la mayoría de los acuerdos son por veinte años. Después de que el periodo haya terminado, el franquiciador a menudo tiene el derecho de recomprar o revender la unidad ${ }^{30}$.

Entonces surge la interrogante: ¿qué es una franquicia?

\section{Las franquicias, concesiones o licencias, como un acuerdo contractual mediante el cual una compañía matriz (franquiciador) le concede a una pequeña compañía o a un individuo (franquiciado) el derecho de hacer negocios en condiciones específicas ${ }^{31}$.}

Esto nos permite resumir de forma simple que un franquiciador tiene el derecho de nombre o de marca registrada y le vende el derecho a un franquiciado, conociendo esto como licencia de producto.

En la forma más compleja, el formato de licencia de negocio es una relación más amplia y continua que existe entre dos partes, donde a menudo comprende un rango completo de servicios, incluyendo selección de sitio, entrenamiento, suministro de productos, planes de marketing y también financiador.

El crecimiento de los concesionarios representa el rápido incremento de dos orientaciones: el apuro de los individuos por llegar a ser sus propios jefes, y la necesidad de las compañías de encontrar formas más eficientes y baratas para expandirse.

En ese sentido, la franquicia o concesionamiento es un convenio con el concesionario en el mercado extranjero, ofreciendo el derecho de utilizar el proceso de fabricación, la marca, la patente, el secreto comercial y otros puntos de valor, a cambio de honorarios o regalías ${ }^{32}$.

La franquicia es un sistema de distribución integrado, controlado por el franquiciador, pero financiado por los franquiciados. Una franquicia acertada es un buen socio en el que el éxito del franquiciador y el del franquiciado están indisolublemente unidos.
También se define la franquicia como un sistema de colaboración entre dos partes jurídicamente independientes, vinculadas entre sí a través de un contrato mediante el cual una de las partes, la empresa franquiciadora, cede a cambio de cierta remuneración económica, el derecho a utilizar su marca comercial y su "saber-hacer" empresarial, por un tiempo limitado y en un territorio determinado ${ }^{33}$.

Otros autores lo definen como un acuerdo (vertical) por el cual el propietario de una marca, nombre comercial u otra presentación de marketing distintiva (franquiciante) otorga una licencia en favor de un minorista (franquiciado) para que se utilice su marca, nombre comercial o presentación, y para disponer su establecimiento de acuerdo al distintivo o formato asociado con el franquiciante. La franquicia responde a la necesidad de una renovación constante de la oferta de mercado, obligada por la imparable y creciente aparición de nuevos competidores y la exigencia de ofrecer nuevas prestaciones.

Kothler $^{34}$ establece que franquicia o concesionamiento es un convenio con el concesionario en el mercado extranjero, ofreciendo el derecho de utilizar el proceso de fabricación, la marca, la patente, el secreto comercial y otros puntos de valor, a cambio de honorarios o regalías.

En resumen, la franquicia es un acuerdo contractual mediante el cual una compañía (franquiciador) le concede a una pequeña compañía o a un individuo (franquiciado) la licencia y el derecho de hacer negocios en condiciones específicas sobre productos o servicios de su titularidad.

\section{Apuntes legislativos de la franquicia en el Perú}

Es importante resaltar que la legislación específica sobre la materia surge recién en la década de los setenta en California, y en América Latina se ha incorporado con distintas denominaciones sin que se hayan concretado norma específica alguna. En Centroamérica, particularmente, se ha legislado sobre el distribuidor en forma tan genérica que el contrato de franquicia puede considerarse alcanzado por sus disposiciones; por ejemplo, en

30 Meyer, H. y Kohns, S. (1992), p. 348.

31 Meyer, Warren G. (1992), p. 329.

32 Kothler, P. (1996), p. 136.

33 Ver Ascencio, Pedro. (1995), op. cit., pp. 65 y 67.

34 Ver Kothler, Phillip. (1996), op. cit. 
Guatemala tenemos la Ley N. ${ }^{\circ} 78 / 71$; en Honduras, Ley N. ${ }^{\circ}$ 50; en Costa Rica, ap. 21, Código de Comercio; en Perú, el Decreto Legislativo N. 807, Decreto Legislativo N. 662 (Ley de Promoción -Seguridad Jurídica- de la inversión extranjera); Decreto Legislativo N.o 807 (Ley sobre facultades, normas y organización del INDECOPI); Decreto Legislativo N. 823 (Ley sobre propiedad industrial y Texto Único Ordenado-TUO de Procedimientos Administrativos del INDECOPI), entre otros.

Latinoamérica es un mercado muy apreciado por las firmas de Europa y Estados Unidos -el país de origen del sistema de franquicias y el lugar donde el sector es más dinámico-. Una de las tendencias más recientes muestra que las empresas en América Latina también intentan ganar mercados más allá de sus fronteras por medio de franquicias. Y así como se inició en Estados Unidos, los recientes análisis de este mercado sacan a la luz otros cambios en el rubro que, a medida que el desarrollo continúe, se reflejarían en el continente latinoamericano.

\section{Naturaleza jurídica}

Las corrientes doctrinarias consideran al franchising como un contrato de colaboración empresarial, que significa un modelo de colaboración entre distintas empresas independientes para que, por medio de la acción común de las mismas, se logre el desarrollo de los negocios en forma más eficaz. Lo que se pretende es un equilibrio, pero en la práctica el franquiciador es quien subordina al franquiciado y a su vez pone a disposición del mismo una técnica empresarial homogénea para asegurar el éxito de la franquicia, y un producto y marca que gozan de una fama y buen nombre en el mercado. Tales elementos son uniformes para todos los franquiciados que integran la red del franquiciante, creando así una imagen de distribución.

Para otros autores, la franquicia contiene todas las características del contrato de concesión manifestando que son de aplicación las normas reguladoras del mismo y agregando las normas relativas a la transferencia de marcas, designaciones comerciales y tecnología.

Desde el punto de vista de nuestro ordenamiento jurídico civil, los autores opinan que se trata de un contrato atípico, innominado, conmutativo, no formal, bilateral, oneroso de ejecución continuada, siéndole de aplicación los principios generales de los contratos, la autonomía de la voluntad y los principios de orden público y buena fe en su celebración y ejecución.

\section{Caracteres jurídicos del contrato}

Entonces, podemos afirmar que el contrato de la franquicia:

- Es un contrato consensual. Que se perfecciona con el consentimiento de las partes.

- Es bilateral. Ya que el contrato genera derechos y obligaciones para las partes que suscriben el contrato.

- Se trata de un contrato atípico. No se encuentra regulado en nuestro ordenamiento jurídico por lo que se le denomina contrato innominado.

- Es un contrato oneroso. Cada una de las partes obtiene una ventaja de su prestación.

- No formal. No se exige ninguna forma específica de cómo debe ser instrumentado.

- Es conmutativo. Porque desde el momento de su celebración cada una de las partes conoce las obligaciones y ventajas que le corresponden.

- Tracto sucesivo. Las obligaciones que se generan para cada parte no se agotan en el momento de la celebración del contrato sino que permanecen más allá de éste.

El contrato es el elemento principal de todo sistema de franquicia en donde todos los detalles y observaciones deben ser claras, precisas, de seguro cumplimiento y deben ser estudiadas minuciosamente. La concesión de uso de la marca registrada, así como la fortaleza y solidez de una red de franquicias, se sustenta en todos los componentes del sistema, como los logotipos, adecuación y decoración, rótulos y signos distintivos que le generan reconocimiento frente a los clientes.

\section{Sujetos que conforman una franquicia}

En el contrato de franquicia intervienen dos sujetos:

a) El franquiciante. Para ser franquiciante es importante contar con una empresa solvente y con prestigio en su área o sector comercial, además de un nuevo criterio de negocio que traiga novedades y valores diferenciales en el producto, en el servicio o en la manera de comercializarlo. 
Este sistema requiere experimentar con anterioridad todo el procedimiento que necesita la franquicia mediante un establecimiento piloto para que puedan enmendarse los posibles errores; de esa manera, se aumentan los conocimientos y se aporta experiencia al franquiciado. En resumen, se puede decir que se necesita tener en consideración el sistema a instrumentalizar y la experiencia del establecimiento piloto; con estos elementos se puede trasmitir todo ese "saber-hacer" (know how) junto con documentación o manuales, así como precontratos y contratos definitivos.

b) El franquiciado. Es aquella persona física o jurídica que, mediante ciertas condiciones, obtiene el derecho a comercializar y explotar productos o servicios bajo técnicas homogéneas y puestas en práctica con una rentabilidad probada y con una marca registrada.

La doctrina en general coincide en indicar que para contrarrestar las aportaciones del franquiciador, el franquiciado deberá:

- Solventar el total de la inversión necesaria para instalar y decorar su establecimiento según proyecto detallado del franquiciador.

- Abonar al franquiciador los cánones de entrada y pagos periódicos establecidos a cambio de los servicios permanentes que recibe de él.

- Disponer del stock suficiente en calidad y variedad, según los mínimos que establece el franquiciador.

- Aplicar el precio de venta sugerido por el franquiciador.

- Respetar todos los aspectos relacionados con la imagen del producto de la franquicia.

- Admitir las visitas del franquiciador e informar continuadamente del desarrollo de su negocio, aceptando las posibles modificaciones que el franquiciador pudiese imponer en función de obtener mejores resultados.

- Como lo estipula el contrato, respetar las exclusividades territoriales y de marca.

- Asumir el compromiso de participar en los cursos de formación que realice el franquiciador.
- Utilizar los métodos de trabajo, directrices comerciales y de gestión general que el franquiciado transmite a través de los Manuales.

- Respetar las características del sistema comercial y de gestión que definen la franquicia acordada.

\section{Elementos del contrato de franquicia}

Sobre los elementos que integran todo contrato de franquicia comercial en el ámbito internacional y nacional, la doctrina ${ }^{35}$ coincide en señalar los siguientes:

a) Licencia de marca. La esencia de todo contrato de franquicia comercial es que el franquiciador sea titular de una marca de un producto o servicio, ya que la clientela es atraída por el renombre y prestigio de la misma y, por supuesto, que el franquiciado además de utilizar su marca, utilice también sus signos y símbolos distintivos, juntamente con una serie de normas con relación a la forma de actuar del franquiciado, en cuanto a la actividad y administración a desarrollar.

b) Transferencia de un know how. El franquiciante tiene la obligación de capacitar al franquiciado sobre la conducción, estructura y organización del negocio, y éste, a su vez, tiene que seguir las instrucciones tal como está suscrito el convenio, logrando una homogeneidad en el producto y en la presentación del mismo. Esto puede incluir desde la decoración del local hasta el listado de proveedores y entidades financieras.

c) Regalías o canon. Es una forma de retribución del franquiciado al franquiciante, ya que estamos frente a un contrato oneroso en contraprestación a los servicios, asistencia, marca, etc., durante la vigencia del contrato.

d) Territorio. Se refiere a la delimitación de un ámbito territorial a favor del franquiciado en donde desarrollará el contrato, el mismo que es un elemento esencial para el éxito de la operación comercial.

e) Asistencia del franquiciador al franquiciado. Normalmente se sintetiza en un manual operativo aunque depende de los términos del acuerdo, pudiendo crearse un centro de asistencia y servicio mínimo para los franquiciados que

35 Véase Comité Belga de Distribución (1997). También ver Alonso, Mariano (2003). 
componen la cadena, donde se brinda información de mercado, técnica o simplemente de compras.

f) La no competencia y/o las posibilidades de subfranquiciar. Se refiere, por un lado, a impedir de forma expresa la posibilidad de que el franquiciador realice negocios competitivos y, por otro lado, prohibiendo o no la posibilidad de subcontratar.

g) Confidencialidad. Consiste en la obligación de secreto, ya que el franquiciado tiene acceso a información confidencial del franquiciador, prolongándose aún por un plazo prudencial posterior a la conclusión del contrato.

h) Plazo de duración del contrato. Por lo general las partes tienden a establecer un plazo lo suficientemente extenso que permita recuperar la inversión inicial hecha por el franquiciador. En el Perú, en virtud de la autonomía de la voluntad, las partes pueden rescindir sin causa y en cualquier tiempo. Lo que se sugiere es que sea en un término prudencial de entre tres a cinco años con opción a renovarlo por iguales condiciones y si fuera en forma automática, mucho mejor.

\section{Clases de franquicia}

Estos contratos y por sus particularidades, en el ámbito internacional y nacional se clasifican ${ }^{36}$ en:

a) Franquicia de producción. Es cuando el franquiciador, además de ser el titular de la marca, fabrica los productos que comercializa en sus establecimientos franquiciados. Aquí se da el caso que el franquiciador actúe de modo protagónico en las compras, seleccionando y negociando los mejores productos y las condiciones más ventajosas con los proveedores.

b) Franquicia de servicio. Diríamos que es el más dinámico y con más desarrollo. Se da cuando el franquiciador cede el derecho a utilizar y comercializar una fórmula o sistema original del servicio que ofrezca con un nombre ya reconocido y que ha demostrado su aceptación en el mercado. En este tipo de franquicia la fórmula original es propiedad del franquiciador, quien la transmite a sus franquiciados, y es la que tiene mayor aceptación en la actualidad. Es de señalar que dentro de este tipo de servicio, el franquiciador le ofrece al franquiciado una fórmula original y específica de prestación de servicios al consumidor. Por su parte el franquiciado provee los servicios al cliente con el mismo nivel de calidad y a los mismos precios. Es importante resaltar que, debido a su carácter abstracto, esta clase de acuerdo necesita una constante colaboración y transmisión de know how por parte del franquiciador. La forma más frecuente de este sistema se da en las cadenas de comida rápida como McDonald's, Kentucky Fried Chicken y Donkin Donuts.

c) Franquicia industrial. La constituyen dos industriales: el franquiciador y el franquiciado. El fabricante del producto cede el derecho a fabricar y comercializar el producto con su marca original, y se necesita de una buena inversión de capital; de esta manera el vínculo es jurídico y económico, pasando por la tecnología, nombre y marca del producto. El franquiciador tiene que ser el titular de la propiedad industrial que cede a sus franquiciados la tecnología y materias primas necesarias para manufacturar un determinado producto y posteriormente venderlo en el mercado. En otras palabras, en esta modalidad de franquicia una industria decide transferirle a otra su tecnología y su propiedad industrial; así el franquiciador adquiere el derecho de producir y distribuir los productos del franquiciador utilizando la tecnología adquirida. Podemos citar como ejemplos más reconocidos los de Coca-Cola, Yoplait, Royal Canin, entre otros.

d) Franquicia-corner. El ejemplo más simple lo tenemos cuando un comerciante tradicional acepta destinar una parte de su local de una forma exclusiva a una determinada marca, bajo determinadas normas como que en la zona destinada sólo deberán haber productos con la imagen y la marca en cuestión; o que se desarrolle dentro de un establecimiento comercial como una tienda por departamentos, donde se brinde un espacio al franquiciado donde se venderán los productos o se prestarán los servicios objeto de la franquicia, según los métodos y las especificaciones del franquiciador. Es decir, es aquella que se desarrolla dentro de otro establecimiento comercial, con un espacio franquiciado donde se venden los productos y/o se prestan los servicios del franquiciador de acuerdo con sus especificaciones.

e) Máster franquicia. Esta modalidad consiste en exportar una franquicia de un país de origen

36 Al respecto ver Comité Belga de Distribución. (1997). Op. cit. pp.30 y ss. 
hacia otro, a través de la figura del máster franquiciado mediante la cual el franquiciador original vende los derechos de su franquicia a una persona física o jurídica para que la desarrolle en el país de destino. El máster franquiciado o franquiciado máster está encargado del establecimiento piloto, además de ser el gestor y responsable del desarrollo y representación del franquiciador de forma exclusiva en su país y será el encargado de seleccionar a los franquiciados y adaptar el negocio a las características específicas del país en el que se desarrolle. Este es otro de los sistemas más utilizados para extender una franquicia a nivel internacional. El máster franquiciado es el responsable de la selección de nuevos franquiciados, de la inversión, publicidad global de la red y en general de todas las relaciones con los franquiciados de su territorio. Este método también es eficaz para sobrellevar las diferencias culturales que podrían impedir que el franquiciador accediera directamente a un nuevo mercado para sus productos o servicios. Debido al conocimiento que tiene el franquiciado en las costumbres y usos e incluso de los vicios burocráticos dentro de su país, puede servir de puente para que el franquiciador expanda sus negocios sin necesidad de involucrarse directamente en muchos países simultáneamente y en un tiempo que no es comparable con el que necesitaría para comprender tales costumbres y usos, con los costos que ello implicaría.

f) Franquicia de distribución. El franquiciador actúa como intermediario en las compras, selecciona productos que son fabricados por otras empresas y los distribuye a través de sus puntos de venta franquiciados en condiciones ventajosas. El franquiciante cede los productos que él mismo fabrica y/o la marca a sus franquiciados a cambio de regalías o precios de compra más altos, situación que se da mayormente en los productos alimenticios, textiles, entre otros, en los que el franquiciador cede al franquiciado la distribución de sus productos junto con el derecho a utilizar su nombre comercial.

g) Franquicia de formato de negocio. En esta modalidad, el franquiciador le ofrece al franquiciado un negocio que ha sido homogeneizado en todos los detalles y exigencias y resumido en manuales; de esta manera, la asistencia del franquiciador le permite al franquiciado instrumentalizar igual o tal como lo haría el franquiciador en un negocio propio. h) Franquicia de formato de tercera generación. El franquiciado recibe un sistema completo para operar el negocio, un plan total que comprende la asistencia por parte del franquiciante en la búsqueda del local adecuado para la instalación del negocio, el entrenamiento y la capacitación del personal en todas las áreas del mismo. El franquiciado recibe manuales de procedimiento, apoyo publicitario, asistencia en la compra de equipos y fuentes adecuadas de materias primas o productos.

i) Franquicia por conversión. Se trata de aquellos acuerdos en los que un negocio ya establecido accede a una cadena de franquicia, adoptando las características de la misma relativas a imagen, el nombre comercial, publicación conjunta, etc.

j) Plurifranquicias. El franquiciado gestiona franquicias diferentes que normalmente suelen ser complementarias y no competitivas. Se trata de franquiciados que asumen la explotación de distintos puntos de venta de distintas cadenas de franquicias.

k) Multifranquicia. El franquiciado tiene más de un establecimiento del mismo franquiciador, y le corresponde un área determinada en la que puede abrir el número de establecimientos que estime convenientes.

1) Franquicia activa. Es aquella en que el franquiciador exige que sus franquiciados sean los que personalmente gestionen y estén al frente de sus establecimientos.

\section{Derecho y obligaciones que se derivan del contrato de franquicia}

El acuerdo de franquicia es una relación de colaboración entre el franquiciador y el franquiciado y deben tener en consideración tres aspectos para que el sistema sea exitoso: la voluntad de trabajar solidariamente, la aceptación de un derecho de transparencia recíproco, y el soporte legal de la fórmula; en esa orientación podemos sintetizar entre los principales derechos y obligaciones de las partes de una franquicia a las siguientes:

\section{a) Obligaciones y derechos del franquiciador}

- Dar los criterios de imagen general y particular, así como evaluar e inspeccionar los locales indicando las correcciones a realizar o las que se deben realizar. 
- Definir el tipo de calidad y marca de los productos que el franquiciado debe vender.

- Administrar el fondo de publicidad pactado.

- Realizar reuniones periódicas para actualizar el sistema de franquicia.

- Capacitar al personal mediante cursos, publicidad, técnicas e instrucciones del sistema para operar mediante manuales que detallen el funcionamiento.

- Puede seleccionar a los proveedores y suministrarles productos y servicios.

- Actos de fiscalizaciones periódicas y limitar o vetar la elección de los locales.

- Definir las condiciones para la revocación o extinción del contrato y sus causales.

\section{b) Obligaciones y derechos del franquiciado}

- Darle al franquiciador un pago inicial por ingresar a la cadena, adquiriendo el derecho de utilización de la franquicia y luego abonar periódicamente un canon por uso de marca y las regalías correspondientes.

- Adecuarse a todos los acuerdos de comercialización y técnicas del franquiciador.

- Adquirir la licencia de utilización de nombre, marca, etc., y dar cumplimiento al programa de capacitación dictado por el franquiciador.

- Guardar la debida reserva o secreto de toda la información suministrada por el franquiciador.

- Cumplir con los aportes porcentuales oportunamente convenidos para las campañas publicitarias.

- Dar intervención al franquiciador en la elección de local o locales en donde se va a establecer la franquicia.

- Aportes para la elección y puesta en marcha del local.

- Adecuar el sistema informático y contable a los requerimientos del franquiciador.

- Dar cumplimiento a la normativa vigente que regula los distintos aspectos que hacen la operatividad de la franquicia.

- Mantener el esquema de atención al público y no ceder ni subfranquiciar.
- Abstenerse de seguir utilizando el nombre y/o la marca una vez concluida la relación contractual.

\section{Rescisión del contrato}

Pueden establecerse como causales de rescisión la revocación arbitraria, la falta de preaviso, la no renovación si no fue convenida o si genera responsabilidad por daños.

También no cumplir con las cláusulas, presentarse a concurso o quiebra, violación de confidencialidad o secreto, el procesamiento por delitos o fraudes vinculados con la franquicia.

\section{Ventajas y desventajas en general que se puedan encontrar en estos contratos}

Entre las principales ventajas y desventajas ${ }^{37}$ de este tipo de contrato innominado podemos encontrar muchas vinculadas con la gestión de los negocios, principalmente pequeños y medianos, entre ellas citaremos algunas:

- Reconocimiento. El sistema de franquicias o licencias es conocido y el nuevo concesionario no tiene que estar abocado en su reconocimiento por lo mismo que la empresa tiene reputación y el producto ofrecido ya es conocido y aceptado por el consumidor.

- Capital de trabajo. Es menos costoso operar un negocio de concesión porque el franquiciador le da al concesionario controles de inventario y otros medios para disminuir los gastos y, si las circunstancias lo requieren, el franquiciador puede también dar apoyo económico y financiero para los gastos operativos.

- Experiencia. La experiencia del franquiciador llena el vacío de la inexperiencia del nuevo propietario.

- Asistencia de gestión. El dueño de empresa pequeña tiene que aprender el manejo de todas las áreas de su negocio, desde las finanzas, las estadísticas, el marketing hasta la promoción de ventas. La asistencia permanente al franquiciado es importante.

- Ganancias. Con el tiempo los costos disminuyen por la franquicia y los convenios sobre

37 Todos los autores coinciden en las ventajas y desventajas de este contrato, entre estos tenemos a Marzorati, Osvaldo (1990) y Bravo Melgar, Sidney A. (2003a), op. cit., pp. 60 y ss. 
suministros, y es donde surgen las ganancias respaldadas por ser parte de una cadena.

- Motivación. Debido a que el concesionario y el franquiciador se benefician del éxito de la operación, ambos trabajan convenientemente para lograrlo.

\section{Otras ventajas del franquiciante}

Para el franquiciante, la celebración de este contrato contiene las siguientes ventajas:

- Ayuda al ingreso al mercado con facilidad y se ve un aumento rápido de las ventas, teniendo el éxito un efecto de bola de nieve.

- Acceder a nuevas fuentes de ingreso de capitales sin perder el posicionamiento de la empresa.

- El sistema de distribución generalmente conlleva a gastos elevados y ser parte de la cadena evitaría los gastos fijos.

- Ayuda en la cooperación con los distribuidores y los negocios locales bien integrados en medio de la ciudad, de la región o del país.

- Ayuda a generar nuevas fuentes de ingresos sustentadas en el soporte técnico comercial que se tiene.

- Favorece las economías de escala y ayuda al desarrollo del sistema de franquicia.

- Los franquiciadores aportan a sus franquiciados una ayuda inicial y continua. Los servicios iniciales comprenden, fundamentalmente, un estudio de mercado, un estudio de localización del restaurante franquiciado, asistencia en la negociación de alquiler, la concepción de la decoración interior del punto de venta, la formación de la mano de obra, y modelos de gestión contable y financiera. Los servicios continuos comprenden el seguimiento operativo, material de promoción, formación de cuadros y empleados, control de calidad, publicidad a nivel nacional, centralización de compras, informaciones sobre la evolución del mercado, auditorías contables y financieras, seguros aprobados, entre otros.

\section{Desventajas de las franquicias}

Existen también desventajas, entre estas tenemos ${ }^{38}$ : a) Derechos. Los derechos que el franquiciador cobra por el uso del nombre de la empresa, los precios cobrados por las provisiones y otros gastos pueden ser muy altos para una localidad particular, de tal manera que se puede incurrir en pérdidas o bajos márgenes de ganancias para el minorista.

b) Menor independencia. Debido a que el concesionario debe seguir los patrones del franquiciador, el minorista pierde algo de su independencia.

c) Estandarización. Los procedimientos son estandarizados y los concesionarios no tienen mucha posibilidad de utilizar ideas propias.

d) Lentitud. Debido al tamaño, un franquiciador puede ser lento para aceptar una nueva idea o adaptar sus métodos a los cambios de condición.

e) Cancelación. Es difícil y costoso cancelar un convenio de concesión sin la cooperación del franquiciador.

f) El control. El franquiciador tiene menos control sobre el concesionario que si montara sus propias instalaciones de producción.

g) El competidor. Si el concesionario tiene mucho éxito, la firma pierde utilidades y cuando termine el contrato podría encontrarse con que ha crecido un competidor.

\section{5. Ámbito de aplicación la franquicia}

El fenómeno de la internacionalización ya no nos trae sorpresas y tratándose más aún de un sector ágil y versátil como las franquicias, éstas tienen que responder con rapidez frente a los cambios económicos y sociales. La orientación creciente de la economía hacia la generación de servicios, la participación de los gobiernos, los negocios, las patentes, y la incorporación de más mujeres al mercado de trabajo y el envejecimiento progresivo de la población son algunas de las tendencias que repercuten en el sector de las franquicias.

Veamos algunas consideraciones generales al respecto: en economía, la franquicia es la posibilidad que tienen los gobiernos y las empresas de ceder a otra empresa el derecho de realizar una determinada actividad económica. El término tiene varias acepciones; por ejemplo, en el caso

38 Véase al respecto Alonso, Mariano (2003), op. cit. pp. 20 y ss. 
de un municipio, éste puede otorgar una franquicia a una empresa privada para que produzca bienes o servicios, lo que se denomina concesión pública, como en el caso de la electricidad o los teléfonos. Las condiciones en que se debe prestar el servicio, las tarifas que se deben cobrar y las condiciones laborales vienen determinadas en un contrato entre las partes. Si se violan las condiciones estipuladas en el contrato, el que cede la franquicia puede emprender acciones legales para revocarla ${ }^{39}$.

En los negocios, el término franquicia alude al derecho exclusivo que concede una empresa a otra para la explotación de su nombre comercial y su logotipo en un determinado país o región, a cambio del pago de una cantidad de dinero y de un porcentaje de los beneficios. A menudo se transfiere incluso el derecho de realizar campañas publicitarias.

El término se aplica también cuando el propietario de una patente permite a otra empresa fabricar el producto; por ejemplo, muchas cervezas no sólo se fabrican en el país de origen sino que también se fabrican en otros países en régimen de franquicia. Las condiciones de las franquicias varían, pero suelen exigir un pago inicial y un porcentaje de las ganancias. Además, el que recibe la franquicia suele estar obligado a comprar a la empresa concesionaria los materiales necesarios, a respetar los diseños y los logotipos, a ejercer la franquicia sólo en determinada región y a no ceder la franquicia a un tercero ${ }^{40}$.

\section{CONTRATO DE KNOW HOW}

Después de la Segunda Guerra Mundial y como consecuencia de los grandes avances industriales y tecnológicos ocurridos en el mundo, el uso de estos contratos de know how de origen anglosajón, comenzó a evolucionar en Estados Unidos y posteriormente se expandió por diversos países de Europa.

El know how se traduce literalmente por "saber cómo" o "saber hacer" y se denomina también secreto industrial o secreto empresarial ${ }^{41}$. Está relacionado con los conocimientos prácticos, técnicas o criterios que se utilizan en la elaboración o diseño de un proyecto y que se pueden volver a utilizar al realizar otros proyectos similares o equivalentes al mismo.

Esta expresión anglosajona viene siendo utilizada en la actualidad con mayor énfasis en el comercio internacional y se utiliza para referirse a conocimientos como técnicas, información secreta, teorías e incluso datos privados -de clientes y proveedores-. El uso de esta modalidad de contrato es muy difundido y suele utilizarse también en la venta de franquicias pues lo que se vende es know how.

En este contrato es importante en el proceso de transferencia de tecnología. En ese sentido, podemos mencionar como ejemplo, que el $25 \%$ de los contratos de transferencia de tecnología en los Estados Unidos celebrados con empresas extranjeras eran de licencia de know how, a diferencia de un $40 \%$ de contratos mixtos de explotación de patentes y de know how. En Alemania, la tercera parte de los contratos de tecnología son de licencia de know how; similar cifra se puede hallar en la Unión Europea mientras que en Japón es posible hallar un índice mayor de cifras de hasta 50\%.

\section{Notas Previas}

Antes de definir know how debemos tener en consideración algunos aspectos relacionados a la propiedad intelectual y a la transferencia de tecnología, entendida como la forma de realizar la transferencia mediante la cesión, la licencia de patentes y secreto empresarial o know how de la empresa.

Los alcances previos que vamos a desarrollar son importantes por el impacto social, comercial y jurídico que tienen estos contratos. Entonces surge la interrogante ¿qué es la tecnología? ¿y la transferencia de tecnología? ¿el conocimiento transferido?, ¿la técnica y la tecnología? ,¿el conocimiento científico y las patentes? Trataremos de responder a dichas interrogantes en este apartado.

Algunos autores sostienen que cuando se habla de tecnología se refiere no solo al bien, sino también al bien incorporado, es decir, el conocimiento. Otros definen la tecnología como todo el conocimiento necesario para el funcionamiento productivo de una empresa. El término puede abarcar hardware (fábricas, máquinas, productos

39 Véase al respecto Dirección General de Comercio Interior (1988).

40 Idem.

41 Al respecto véase, Ribó Duran, Luis. (1998). 
e infraestructura, así como laboratorios, caminos, sistemas de distribución de agua y facilidades de depósito), y software, que incluye componentes inmateriales como el know how, así como la experiencia del conocimiento, las formas de organización, y la educación ${ }^{42}$.

Otros sostienen que la tecnología es solamente conocimiento, pero aplicable a la producción y obtención de bienes de capital, quedando muy reducido el concepto de tecnología dentro de la actividad comercial, ya que la producción industrial y la obtención de bienes de capital apunta hacia la comercialización; así, se excluye cualquier otro fin que pueda alcanzarse con esos conocimientos ${ }^{43}$. La tendencia mayoritaria sostiene que la tecnología sólo comprende conocimientos sistemáticos y experimentales, los cuales pueden usarse para la consecución de cualquier fin, condicionado a la satisfacción de necesidades; es decir, se trata de conocimientos útiles en el sentido más amplio posible. Está demostrado que el conocimiento humano no está restringido solo al campo de la comercialización, también el conocimiento encuentra una aplicación no industrial, aunque sí económica. En este sentido, Antonorsi señala que:

El conocimiento tecnológico -tecnología- es el conocimiento sistemático y experimental de los medios eficaces para el logro de fines, por lo tanto, el concepto de tecnología involucra todo conocimiento útil para la satisfacción de necesidades, teniendo connotación económica y no exclusivamente comercial ${ }^{44}$.

En relación a la transferencia de tecnología no existen mayores discrepancias sobre esta modalidad que consiste en un acto por el cual una persona, natural o jurídica, transfiere a otra persona, natural o jurídica, un saber o conjunto de conocimientos útiles para el logro de fines, o sea, se refiere a un conjunto de conocimientos. De esta forma, la denominación "transferencia de tecnología" hace referencia a un género o compartimiento en el cual se incluye todo acto por medio del cual se produce una transmisión de conocimientos.
En la doctrina existe una clasificación sobre transferencia nacional o internacional y transferencia horizontal o vertical, entre otras clasificaciones en función de los objetivos que se busque.

La transferencia de tecnología es vertical cuando se realiza desde un órgano oficial del Estado hacia un sector con el que normalmente está ligado. La transferencia de tecnología es nacional cuando ocurre dentro del territorio de un país; por ejemplo, la transferencia de tecnología de una industria a favor de otra industria, dentro del territorio de un mismo Estado, y la transferencia es internacional si es realizada desde el territorio de un Estado hacia el territorio de otro u otros Estados, no importando la nacionalidad de las personas intervinientes en la transferencia, pues lo determinante es que el conjunto de conocimientos involucrados en la transferencia se traslade desde el territorio de un Estado hacia el territorio de otros u otros Estados.

En cambio, sobre el conocimiento transferido, el debate está en relación al objetivo de la transferencia de tecnología, es decir el conocimiento tecnológico, pues no existe un criterio unánime acerca de lo que debe entenderse por tal tipo de conocimiento, sin embargo tomaremos algunas definiciones como la técnica en la aplicación de los conocimientos útiles que implica una relación entre el operario y el medio. La técnica está orientada a una situación de hecho, a un saber-hacer, y debe ser entendida como medios creados por los seres humanos para transformar la naturaleza y satisfacer sus necesidades ${ }^{45}$. Este mismo autor hace una diferencia importante en relación a la técnica y la tecnología, ya que la técnica está referida tanto a las habilidades para realizar cierta operación como a los bienes resultantes de tal operación. La técnica considerada en sí misma, insistimos, no es conocimiento útil para la consecución de un fin sino la aplicación del conocimiento útil, lo que marca diferencias con el concepto tecnología que comprende el bien en el cual se encuentra incorporado el conocimiento, como maquinarias, infraestructura, etc ${ }^{46}$.

42 Ver el estudio que patrocinó el Departamento de Tecnología de los Estados Unidos en 1978 entre 120 empresas transnacionales de dicho país, con la finalidad de saber cuál era la posición de estas empresas ante el proceso tecnológico. En: Consejo de las Américas. Public policy in tecnology transfer. Vol. 1, pp. 40-42 citado por Borges B., Denis. (1988), p. 525.

43 Ver Paiva Hantke, Gabriela (1991), pp. 11-12. También Organización Mundial de la Propiedad Intelectual (1977), pp. 17-28.

44 Antonorsi, Marcel. Ciencia, tecnología y técnica: ensayo esquemático de definición conceptual. Citado por García L., Humberto (1989), p. 24.

45 Antonorsi, Marcel (1989). p 25.

46 Véase al respecto: Consejo de las Américas. Public policy in tecnology transfer. Vol. 1, pp. 40-42. Tomado de: Borges B., Denis (1988), p. 525. Paiva Hantke, Gabriela (1991), op. cit., pp. 11-12. Organización Mundial de la Propiedad Intelectual (1977), pp. 17-28. 
Y en cuanto al conocimiento científico, tradicionalmente se ha sostenido que tiene por características el ser racional, metódico, sistemático, exacto, verificable y por consiguiente falible. El conocimiento científico se encuentra libre de subjetividad, su consecución no aspira a fin alguno. Es el conocimiento por el conocimiento ${ }^{47}$.

Este concepto ha generado debate por el surgimiento de la ciencia aplicada que consiste en el conjunto de conocimientos racionales, metódicos, sistemáticos, verificables y falibles adquiridos con la finalidad de ser usados industrialmente. Teniendo en consideración lo expuesto anteriormente, las relaciones y diferencias entre la ciencia, la tecnología y la técnica se resumiría en lo siguiente: la ciencia es el conocimiento puro adquirido metódicamente que no persigue ningún fin en sí mismo. La tecnología es el conjunto de conocimientos aplicables a un fin útil sin importar la naturaleza del conocimiento (científico o no). La técnica apunta hacia la aplicación o materialización del conocimiento utilizable. Para acentuar aún más la diferencia entre técnica y ciencia podemos aseverar que la ciencia produce teoremas -enunciado de conocimientos evidentes sobre algo y que exige demostración-, mientras que la técnica produce conocimiento de alguna cosa por haberla construido y que en sí misma es la demostración ${ }^{48}$.

El debate continúa en la doctrina sobre la concepción de ciencia-tecnología-técnica, donde se plantea además que existen casos en los cuales la tecnología no comprende conocimientos científicos sino, fundamentalmente, conocimientos técnicos; sin embargo, es de recordar que la tecnología incorpora conocimientos sistemáticos y experimentales destinados a un fin, por ejemplo, se puede indicar cómo preparar una torta.

Y, por último, en cuanto a la noción de patentes, estas se entienden como una modalidad de los derechos de propiedad industrial que consiste en el título que el autor de un invento apto de aplicación industrial puede solicitar y que le conferirá el derecho exclusivo de explotación en beneficio propio durante un tiempo determinado. En esa orientación los distintos países tratan de garantizar -mediante sus ordenamientos jurídicos- la protección de las patentes con el objetivo de que los titulares puedan aprovechar una explotación exclusiva de la tecnología; de esa manera se incentiva la creación e innovación de las personas, lo que aumenta el patrimonio intelectual. Normalmente, las figuras o sistemas jurídicos que se proponen garantizar el uso exclusivo de la tecnología son el sistema de patente y el sistema de secreto empresarial o know how.

El sistema de patente, según la doctrina ${ }^{49}$, tiene como objetivo garantizar al autor de una invención la exclusividad de la explotación sobre la misma, durante un tiempo determinado por la ley para que ninguna otra persona puede ejercer algún derecho de explotación sobre ella, salvo que tenga la autorización del inventor o autor. Sin embargo, existen diferentes lecturas sobre lo que debe entenderse por invención o novedad inventiva o simplemente novedad, que viene a ser el requisito fundamental de un invento que se considere patentable.

La novedad, por una parte, puede entenderse como originalidad o creación de algo que no existía; por otra, conlleva a la aceptación de falta de divulgación, es decir, que existiendo la cosa, esta no habría traspasado la órbita privada de su creador. En ambos casos se habla también de invención nueva ${ }^{50}$. Otros afirman que "La invención no se apoya, por consiguiente, en nada material ni físico"51. En ese sentido, se entiende que la invención como idea lleva a un conocimiento y por lo mismo que tiene que solucionar un problema técnico. Previamente se debe tener conocimiento sobre el objeto o el fin propuesto; en otras palabras, la invención, al ser difundida, alcanza la categoría de conocimiento útil, ya sea para su inventor o para los terceros. Asimismo, es de indicar que no siempre toda tecnología es patentable si no cumple con los requisitos de carácter general que se tienen a nivel internacional como son:

- Novedad, en el sentido de que la invención-léase tecnología- no debe haber sido divulgada o conocida antes de la solicitud de patentar, salvo ciertas excepciones contempladas en la ley.

- Aplicación industrial, esto es, que la invención debe ser aplicable más no necesariamente aplicada en el sector industrial.

47 Ver Bunge, Mario (1997), pp. 189 y ss. También véase Oceano Centrum (2006). Enciclopedia del Managemet.

48 Ramis, Pompeyo (1995), pp. 29-30.

49 Ver, entre otros: Blanco J., Araceli (1999); Breuer M., Carlos (1957); Díaz Velazco, Manuel (1987).

50 Véase Ribó Durán, Luis (1998).

51 Baylós C., Hermenegildo (1993), p. 695. 
- La invención debe superar el estado de la técnica o no ser un conocimiento obvio para cualquier persona versada en la materia ${ }^{52}$.

\section{Definición}

Como no se tiene una definición de este tipo de contratos en el Código Civil peruano debemos acudir a las definiciones doctrinales y a la legislación extranjera.

Para la ley alemana, know how es sinónimo de adelanto inventivo, procedimiento de fabricación, construcciones y adelantos enriquecedores de la técnica, que deben ser secreto de las empresas.

La legislación española, específicamente el Decreto N. ${ }^{\circ} 1.750 / 87$ en su artículo 1, inciso a), al referirse indirectamente al know how estipula que se trata de conocimientos secretos no patentados aplicables a la actividad productiva.

Para algunos el know how es el negocio jurídico en virtud del cual una de las partes (transferente) se compromete a poner a disposición de la otra parte (adquiriente o receptor) los conocimientos técnicos constitutivos del know how de modo definitivo, desprendiéndose de ellos en todo, en parte o bien a comunicar dichos conocimientos, posibilitando su explotación por un tiempo determinado comúnmente en forma de cantidad de dinero, calculada como porcentaje sobre producción de venta.

La Cámara Internacional de Comercio formuló la siguiente definición: es la totalidad de los conocimientos, del saber especializado y de la experiencia volcadas en el procedimiento y en la realización técnica de la fabricación de un producto que puede, por tanto, ser denominado art de fabrication (know how). Se precisó, a su vez, que este concepto no sólo concierne a fórmulas y procedimientos secretos, sino también a una técnica que guarde conexión con procedimientos de fabricación patentados y que sea necesaria para hacer uso de la patente. Puede también estar referido a procedimientos prácticos, particularidades y conocimientos técnicos especializados que fueron obtenidos por un productor a través de investigaciones y que no deben aún ser adquiridos por la competencia.

El Bureau Internationaux Reunís pour la Protection de la Propieté Industrielle, Rétraire et Artistique (BIRPI), que traduciendo viene a ser La Unión de Oficinas Internacionales para la Protección de la Propiedad Industrial, Literaria y Artística, en su modelo de ley para países en desarrollo con referencia a las invenciones, describe al know how en su artículo 53/1 como los procedimientos de fabricación o conjunto de conocimientos para la utilización y aplicación de técnicas industriales, a su vez acotan que el know how no constituye una forma de protección jurídica industrial. Para el BIRPI, la esencia del know how se halla enmarcada en la razón de que el inventor prefiere mantener en secreto los elementos desconocidos de su invento en vez de revelarlos completamente mediante la solicitud de patente.

El Reglamento N. ${ }^{\circ} 556 / 89$ de la Comunidad Económica Europea, hoy denominada Unión Europea, en su artículo 1.7.5) describe los acuerdos puros de licencia de know how señalando que se trata de aquellos por los que una empresa denominada licenciante accede a comunicar el know how con o sin la obligación de revelar cualquier mejora posterior a otra empresa denominada el licenciatario, para su explotación en el territorio concedido. A su vez, en el mismo artículo 6 define los acuerdos mixtos de licencia de know how y de licencia de patentes como aquellos no exentos, en concordancia con el Reglamento N. ${ }^{\circ} 2.349 / 84$, por los que se concede una tecnología constituida a la vez por elementos no patentados en uno o más estados miembros.

En cambio, la Asociación Internacional de Protección Jurídica Industrial conceptúa al know how como los conocimientos y experiencias de naturaleza técnica, comercial, administrativa, financiera o de otra naturaleza, aplicables en la práctica a la explotación de una empresa o al ejercicio de una profesión. Para el profesor Gómez Segade, el know how es:

todo conocimiento reservado sobre ideas, productos o procedimientos industriales, $o$ sobre ideas o procedimientos comerciales, que el empresario, por su valor competitivo de la empresa, desea mantener ocultos ${ }^{53}$.

El know how es conceptuado como la convención mediante la cual una persona natural o jurídica se obliga a hacer gozar al contratante de los derechos que posee sobre ciertas fórmulas y procedimientos secretos, en un tiempo determinado, y a través de un precio que el citado se

52 Ibid., p.695. 
obliga a pagarle ${ }^{54}$. Es todo conocimiento reservado sobre ideas, productos o procedimientos industriales que el empresario -por su valor competitivo para la empresa- desea mantener ocultos. En esencia, es un procedimiento de fabricación o reproducción que, originariamente se incluía en el concepto de patente pero, con la sofisticación técnica actual, constituye un cuerpo de información superpuesto o añadido a la patente. El objeto del know how puede ser desde una invención patentable pero no patentada, hasta la más insignificante práctica manual que sirve para resolver determinados problemas técnicos ${ }^{55}$.

En términos generales, se puede definir que es un contrato atípico e innominado, mediante el cual una persona jurídica o natural conviene con otra de similar naturaleza el otorgamiento de una fórmula secreta de fabricación o elaboración de algún artículo, a cambio de un precio y tiempo convenido. Los conocimientos secretos que se transfieren son de orden industrial, tecnológico, entre otros.

\section{Naturaleza jurídica}

El contrato de know how fue desarrollado por la práctica. No ha sido especialmente legislados, y su contenido puede asumir diversas formas. Al no existir una disposición legal podemos concluir lo siguiente:

- Es consensual. Ya que se perfecciona por el consentimiento de las dos partes que intervienen en el contrato mismo.

- Es sinalagmático. Ya que a través del mismo nacen obligaciones y derechos para ambas partes.

- Es un contrato mercantil.
- Se trata de un contrato mixto o complejo. Por tanto su régimen jurídico será de acuerdo a lo pactado por las partes; por analogía de las normas que regulen los contratos más afines, del que se trate o, por último, serán de aplicación los principios generales del derecho de las obligaciones.

\section{Características}

Entre las características del contrato de know how podemos mencionar:

- Es un contrato principal. En razón a su autonomía e independencia ya que para existir no depende de otros contratos.

- Es un contrato atípico. Decimos esto porque no tiene una norma propia que regule los derechos y las obligaciones de las partes contratantes; a tal efecto, cabe remitirse en principio a la autonomía de la voluntad de las partes, teniendo siempre en cuenta las limitaciones establecidas en nuestro ordenamiento jurídico (artículo V del Título Preliminar del Código Civil, a su vez las normas concordantes establecidas en los artículos 140 -definición y elementos del acto jurídico ${ }^{56}$-, 219 -referido a la nulidad del acto jurídico- y 1354 -libertad contractual ${ }^{57}$ - del mismo texto legal); en segundo lugar, acudiremos a las normas supletorias, tratándose de nuestro país a las establecidas en la sección primera del libro VII de nuestro ordenamiento sustantivo (artículo 1353 del Código Civil ${ }^{58}$ ) y, en tercer lugar, respetando la prelación descendente a los usos y costumbres de la contratación en general.

- Es innominado. Ello en virtud de no contar con un nomen iuris, es decir, denominación jurídica única.

53 Ver, Gómez Segade, J. A. (1981), p.78. Otros autores indican que el título apropiado para estos contratos es el de licencia de know how y lo conceptúan como el negocio jurídico celebrado entre personas físicas o jurídicas en virtud del cual una de ellas, el licenciante, titular de un know how, autoriza a otra persona denominada el licenciatario o receptor a explotarlo durante un tiempo determinado y con este fin se obliga a ponerlo en su conocimiento en razón de lo cual el licenciatario o receptor se obliga por su parte a satisfacer un precio cierto en dinero o en especie fijado comúnmente en forma de suma de dinero calculada en función del volumen de fabricación o ventas de productos o servicios realizados con el empleo del know how licenciado.

54 Ver Bravo Melgar, Sydney Alex (2003b), p. 503.

55 Véase al respecto Ribó Duran, Luis (1998), op. cit.

56 El artículo 140 indica que el acto jurídico: "Es la manifestación de voluntad destinada a crear, regular, modificar o extinguir relaciones jurídicas, para su validez se requiere: agente capaz, objeto física y jurídicamente posible, fin lícito y observancia de la forma prescrita bajo sanción de nulidad".

57 El artículo 1354 indica: "Las partes pueden determinar libremente el contenido del contrato, siempre que no sea contrario a norma legal de carácter imperativo".

58 El artículo 1353 dice: "Todos los contratos de derecho privado inclusive los innominados, quedan sometidos a las reglas generales contenidas en esta sección, salvo cuando resulten incompatibles con las reglas particulares de cada contrato". 
- Es un contrato exclusivo. Porque no es posible generar sub-contrataciones.

- Es un contrato moderno. Ello en razón a los pocos años de aplicación que tiene en nuestro país esta modalidad, sobre todo con dicha denominación.

- Es un contrato bilateral. La razón es el número de partes contratantes.

- Es una modalidad contractual sinalagmática. Ello en función a la existencia de prestaciones recíprocas y porque el licenciatario se obliga al uso y explotación del know how; por su parte, el licenciante se obliga a proporcionarle los conocimientos necesarios.

- Es un contrato oneroso. Puesto que los derechos están representados por los conocidos royalties (regalías) y/o forfeits (pago en una sola armada).

- Enmarca conocimientos vinculados con fórmulas o procedimientos secretos industriales y/o comerciales.

- Los conocimientos transferidos vía know how están constituidos por un valor de orden económico.

- Es un contrato consensual. Se perfecciona con el consentimiento de las partes contratantes. Si bien por seguridad jurídica se celebra por escrito, ello no desvirtúa la consensualidad del mismo, ya que éste no se configura en un requisito sine qua non, puesto que estamos hablando de un contrato ad probationem. Si el licenciante es extranjero debemos remitirnos a la Decisión 291, la cual obliga la literalidad del contrato estableciéndose que éste debe constar por escrito y deberá a su vez registrarse en el organismo competente del país donde se celebra el acuerdo. Tratándose de Perú, dicho organismo es INDECOPI, específicamente la Oficina de Signos Distintivos y Transferencia de Tecnología Extranjera.

- Es un contrato constitutivo. Ello en razón a la constitución de derechos y obligaciones para las partes contratantes, lo cual significa que se trata de un contrato primigenio.

- Es un contrato de naturaleza eminentemente mercantil.
- El contrato de know how puede ser de tracto sucesivo. Ello si las prestaciones del licenciatario son periódicas (royalties) y/o serán de ejecución instantánea si se patentizan en un pago único (forfaits).

- El know how se configura en un contrato conmutativo. Puesto que desde el momento de la celebración del mismo las partes ya conocen los beneficios y posibles sacrificios que pudieran importar.

- Idioma del contrato. Los contratos celebrados entre partes de distinta nacionalidad generalmente son redactados en dos idiomas. Teniendo en cuenta la dificultad que representa la traducción de esos documentos a otros idiomas, existe el peligro de que el documento sea mal interpretado; por tanto, es importante establecer cuál de las dos versiones será la determinante. Las partes deben ser muy diligentes en la correcta traducción, debiendo encomendarse dicha labor a un traductor idóneo puesto que en la praxis, de existir alguna controversia, un juez extranjero considerará en primer lugar la versión que está redactada en su propia lengua.

- Duración del contrato. El contrato de know how puede tener duración determinada o indeterminada, dependiendo al acuerdo al que hayan arribado las partes interesadas en él.

- Conclusión del contrato. El contrato de know how puede concluir por diversas causas, entre éstas tenemos la rescisión o resolución, nulidad o anulabilidad. En ese sentido, en primer lugar, es importante tener en consideración:

- Término de duración. Si se cumplió el plazo estipulado por las partes contratantes, el licenciatario no podrá seguir aplicando los conocimientos transferidos por el licenciante, obligándose a su devolución por lo mismo que el know how tiene el objetivo de una transferencia en uso, mas no en propiedad. En caso que no existiera un plazo determinado y si se tratara de un contrato de tracto sucesivo nos remitiremos a lo dispuesto por el artículo 1365 del Código Civil Peruano ${ }^{59}$, el cual ad pédem litterae señala que en los contratos de ejecución

59 El artículo 1365 indica: "En los contratos de ejecución continuada que no tengan plazo convencional o legal determinado, cualquiera de las partes puede ponerle fin mediante aviso previo remitido por la vía notarial con una anticipación no menor de treinta días. Transcurrido el plazo correspondiente el contrato queda resuelto de pleno derecho". 
continuada que no tengan plazo convencional o legal determinado, cualquiera de las partes puede ponerle fin mediante aviso previo remitido por la vía notarial con una anticipación no menor de treinta días. Transcurrido el plazo correspondiente, el contrato queda resuelto de pleno derecho.

- Por rescisión o resolución. Estas modalidades de conclusión o terminación del contrato de know how nos llevan a recurrir al Código Civil, artículo 1370 que señala: "La rescisión deja sin efecto un contrato por causal existente al momento de celebrarlo" y el artículo 1371 que indica: "La resolución deja sin efecto un contrato válido por causal sobreviniente a su celebración". El primer artículo expone que la rescisión deja sin efecto un contrato por causal existente al momento de celebrarlo; el segundo numeral establece que la resolución deja sin efecto un contrato válido por causal sobreviniente a su celebración. Es de comentar que a lo expuesto le es aplicable a su vez lo estipulado en los numerales 1428 (resolución del contrato por incumplimiento) y siguientes de nuestro Código Civil en lo que respecta al incumplimiento o imposibilidad de la prestación (resolución); asimismo el artículo 1447 y siguientes relacionados a la rescisión por lesión.

- Nulidad o anulabilidad del contrato. El know how, a su vez, puede terminar por nulidad o por anulabilidad del mismo; en ese sentido, nos remitiremos al Código Civil peruano a los artículo 219 que se refiere a la nulidad del acto jurídico ${ }^{60}$, y 221 , que se refiere a las causales de anulabilidad ${ }^{61}$.

Entre otras causales de conclusión del contrato de know how podemos mencionar las de conclusión de las obligaciones; así tenemos que podrán extinguirse las obligaciones nacidas del contrato de know how por compensación, condonación, transacción, consolidación, mutuo disenso, entre otros.

\section{Formación del contrato de know how}

El know how está compuesto por diferentes fases de conocimientos técnicos, entre estos tenemos los siguientes:

- Objetos como los inventos no patentados, piezas de prueba, modelos no registrados, instalaciones de mecanización, piezas singulares, herramientas, entre otros.

- Los datos y antecedentes técnicos como los planos, dibujos, fórmulas, cálculos, entre otros.

- Procedimientos y diseños para la construcción, producción o explotación del producto, o su aplicación del procedimiento de fabricación.

- Experiencias de explotación o recomendaciones de ejecución.

- Fórmulas técnicas.

- Explicaciones suplementarias concernientes a una patente.

- Indicaciones sobre la planificación del trabajo y condiciones que debe tener el personal.

\section{Elementos del know how}

Los elementos con los que cuenta un contrato de know how pueden ser los siguientes:

a) Ámbito técnico. A nivel internacional, se refieren, principalmente, a las fórmulas, recetas y cálculos; entre estos tenemos una extensa lista y podemos señalar los siguientes: los cálculos estáticos, anotaciones sobre los trabajos de desarrollo realizados, tablas y resultados de validez general en su aplicación especial a un producto determinado, dibujos de construcción, resultados y actas de ensayo, listas de piezas, indicación de la calidad del material, dibujos parciales para subcontratistas, hojas de normas que proporcionen información sobre un trabajo de estandarización realizado, adiestramiento de colaboradores de otra empresa, documentos concernientes a trabajos

60 El artículo 219 se refiere a las causales de nulidad del acto jurídico: "Cuando falta la manifestación de voluntad del agente o se ha practicado por persona absolutamente incapaz, salvo lo dispuesto en el artículo 1358, su objeto sea física o jurídicamente imposible o cuando sea indeterminable, su fin sea ilícito, cuando adolezca de simulación absoluta, no revista la forma prescrita bajo sanción de nulidad y cuando la ley lo declara nulo en el caso del artículo V del Título Preliminar, salvo que la ley establezca sanción diversa".

61 El artículo 21 indica las causales de anulabilidad; entre estas tenemos: "Por incapacidad relativa del agente, por vicio resultante de error, dolo, violencia o intimidación, por simulación, cuando el acto real que lo contiene perjudica el derecho de tercero y cuando la ley lo declare anulable". 
de programación, cálculos de cantidades para montaje a la intemperie, índices alfabéticos de aparatos, informes de construcción, volúmenes de lotes óptimos para piezas estandarizadas, normas de recepción y ensayos, documentos de fabricación, dibujos, planes de trabajo con indicación de tiempo y tolerancias, comunicaciones de cambios acontecidos en forma de mejoramientos continuos, hojas de normas que proporcionan información sobre un trabajo de estandarización realizado, indicación de la calidad del material, entre otros.

b) Ámbito mercantil. Coinciden casi todos los autores en indicar los elementos que lo componen, entre estos tenemos el adiestramiento de colaboradores o de personal de otra empresa, métodos de publicidad, documentos relacionados a la financiación, documentos referentes a la venta y distribución, documentos relacionados a los trabajos de programación en el ámbito mercantil, y a la organización del establecimiento, fichero de clientes y proveedores.

\section{Derechos y obligaciones que derivan del contrato de know how}

Señalaremos a criterio de la doctrina cuáles son los derechos y obligaciones tanto del licenciante como del adquiriente.

a) Derechos. El principal derecho que podemos indicar sería el de percibir una contraprestación pecuniaria por parte del licenciatario por todos los conocimientos transferidos en uso a éste, y otro derecho fundamental que tiene el licenciante sería el de supervisar el fiel cumplimiento de las cláusulas del contrato suscrito.

b) Obligaciones del licenciante al transmitente. Podemos señalar las siguientes:

- Otorgar el know how. El licenciante de know how deberá transferir los conocimientos técnicos, modelos o avances que constituyen en sí el objeto del know how, esto significa la entrega de fórmulas, objetos, herramientas, manuales, moldes, documentos de fabricación, informes de construcción o elaboración, memorias, proyectos e instrucciones complementarias.

- Garantía de los resultados. Aunque poco frecuente, otra de las posibles obligaciones que puede estar dentro del contrato sería la garantía de resultados, que se incluiría en una cláusula. En esta el licenciante garantiza el aumento de la producción y de ventas por parte del licenciatario, a consecuencia de la tecnología que adquiere.

- Asistencia técnica. En el contrato de know how la asistencia técnica por parte del licenciante a favor del licenciatario es importante por lo complejo que resulta algunas veces la transmisión de conocimientos secretos de fabricación o elaboración de algún punto. Muchas veces se da el caso que una empresa tenga instalaciones ortodoxas e inadecuadas, por lo que tendrá dificultades para adecuarse a unos medios de producción innovadores y de alta tecnología, basados en la experiencia de otra empresa generalmente extranjera; en ese sentido se procede a apoyar con personal técnico especializado con el fin de efectuar las transformaciones requeridas.

- Pacto de exclusividad. En el contrato de know how es posible incorporar una cláusula de exclusividad, para que el licenciatario pueda exigirle al licenciante el no contratar con un tercero, con el fin de transmitirle y autorizarle el uso del know how. En otras palabras ningún tercero podrá explotar vía dicho know how dentro de una determinada circunscripción territorial; sin embargo, cabe aclarar que la cláusula de exclusividad no es un elemento del know how; en tal sentido, si no está expresamente establecido en el contrato no se tomará en cuenta.

- Acuerdos enlazados. Asimismo, se puede imponer como obligación lo que en Estados Unidos se denomina tying arrangements, ello constriñe al licenciante a proporcionarle al licenciatario materias primas, equipos o servicios bien sean los suyos o de un tercero designado anticipadamente; sin embargo, es de señalar que no es elemento esencial del contrato de know how. Asimismo debe tenerse en cuenta que este tipo de acuerdos se encuentra prohibido para aquellos negocios en los cuales el licenciante es extranjero, tal cual se encuentra establecido en la Decisión $291^{62}$ concerniente a la importación de tecnología.

c) Obligaciones del adquiriente. Las principales obligaciones son las siguientes:

62 Se refiere al I Acuerdo de Cartagena sobre el Régimen Común de Tratamiento los Capitales Extranjeros y sobre Marcas, Patentes, Licencias y Regalías. 
- Obligación del pago. La principal obligación que tiene el licenciatario radica en el pago que deberá efectuar al licenciante por los conocimientos cedidos. Este pago se puede resumir de diversos modos, las dos modalidades más comunes son: el pago total en un solo bloque conocido en inglés como los forfeits o a través de regalías (royalties) generalmente mensuales deducidas de las utilidades que genere a favor del beneficiario (licenciatario). Dichas sumas serán depositadas en la cuenta bancaria del licenciante, la cual es fijada con anticipación. En cuanto al porcentaje, ello queda sujeto a la liberalidad de las partes.

- Guardar el secreto. Otra de las obligaciones que tiene el licenciatario es la de guardar los conocimientos transferidos, lo que deberá estar estipulado en el contrato; naturalmente, si se divulgaran éstos, se estaría desnaturalizando el contrato de know how. A su vez cabe comentar que los contratos son ley para las partes y es obligatorio su cumplimiento, siempre y cuando no se contravenga el orden público ni las buenas costumbres (concordado con los artículos V del Título Preliminar del Código Civil, artículos 140, 219 y 1354 del mismo texto legal).

- Retorno de conocimiento. Una de las relevantes obligaciones que enmarca el licenciatario radica en la devolución de los conocimientos cedidos por parte del licenciante y ello al cabo de la conclusión del contrato. Asimismo, durante la vigencia del contrato el cedido está en la obligación de comunicar al licenciante las ventajas o perfeccionamientos que el empleo del know how le ha generado, a esta cláusula los anglosajones la denominan grant back. Lo citado consiste en la comunicación que efectuará el usuario de todas las mejoras y modificaciones que requiera el know how. Cabe comentar que esta cláusula debe estar expresamente establecida en el contrato, ya que no es elemento esencial del know how. Es importante precisar que en contratos de know how, cuando el licenciante es extranjero tal como expone Arias Schreiber, la decisión 291 del acuerdo de Cartagena (Régimen Común de Tratamiento los Capitales Extranjeros y sobre Marcas, Patentes, Licencias y Regalías) prohíben esta clase de acuerdos. A tal efecto el artículo 14 de la Decisión 291 prohíbe las siguientes cláusulas:
- Obligación del licenciatario de transferir al licenciante los inventos o mejoras obtenidos con el uso de la tecnología objeto del know how.

- Obligación de pagar regalías por patentes o marcas no utilizadas o vencidas.

- Cualquier limitación a la exportación de productos elaborados en base a la tecnología respectiva. Cabe resaltar que en lo concerniente a esta limitación existe la posibilidad de que pueda dispensarse en casos excepcionales y anteladamente calificados por el organismo nacional ad hoc.

- Obligación del licenciatario de adquirir bienes, tecnologías o productos de una fuente determinada, o de utilizar permanentemente personal indicado por el licenciante.

- Establecimiento del derecho, por parte del licenciante, a fijar los precios de venta o reventa de los productos elaborados en razón de la tecnología respectiva.

- Restricciones al volumen y estructura de la producción.

- Prohibición de emplear tecnologías competidoras.

- Opciones de compra, totales o parciales, a favor del licenciante.

- El licenciatario está obligado a facilitarle las labores de supervisión que realice el licenciante, a fin de verificar si se están cumpliendo las cláusulas del contrato y para efectuar el control de calidad del producto respectivo.

\section{Consideraciones importantes a tener en cuenta en estos contratos}

- Las partes deberán expresar con toda claridad su voluntad en todos los aspectos del contrato, eludiendo ambiguiedades para evitar posterior interpretación de lo pactado.

- La búsqueda de un equilibrio entre las contraprestaciones de los que intervengan en el contrato.

- Describir el objeto del contrato lo más ampliamente posible por medio de anexos incorporados al mismo que incluyan la descripción detallada y acompañada de planos, memoria, entre otros, respecto a la tecnología objeto de la transmisión. 
- Describir el ámbito territorial de explotación del know how.

- El tiempo de duración y las posibles prórrogas.

- Las operaciones que el adquirente puede desarrollar con la técnica adquirida.

- El sector industrial en que el know how puede ser explotado.

- Cuando implique la transferencia de tecnología extranjera a favor de una empresa nacional, esta se precisará en forma escrita para cumplir los trámites del procedimiento de verificación.

- Cuando el contrato de know how contenga cláusulas que pueden ser restricciones a la competencia, convendrá acompañar con un informe $o$ autorización del Tribunal de Defensa de la Competencia.

- En los supuestos de contratos de know how mixtos, es decir, cuando junto con la transmisión de la técnica secreta se transmita algún derecho de la propiedad industrial, será necesaria su inscripción en el Instituto Nacional de Defensa de la Competencia y Protección de la Propiedad Intelectual (INDECOPI).

\section{Diferencias con otras figuras jurídicas}

La carencia de una reglamentación legal ha hecho que se apliquen a esta clase de contratos otras figuras jurídicas afines como:

a) Licencia de Patentes. Es donde se muestra mayor afinidad; sin embargo, hay puntos esenciales de diferencia: toda innovación técnica debidamente patentada está protegida en virtud de este acto jurídico, no siendo un secreto de la empresa que lo ha efectuado, dado el carácter público del Registro de Patentes y Marcas, condición que no se da en los contratos de know how ya que el secreto de la nueva técnica o de la invención es fundamental y, como hemos dicho, la mayor parte de las veces no se llega a patentar.

b) Contratos de compra-venta. También hay una importante distinción entre los contratos de compra-venta con los de know how. Por el contrato de compra-venta uno de los contratantes se obliga a entregar una cosa determinada y el otro a pagar por ella un precio cierto en dinero o signo que lo represente. En el know how el transmitente no vende sus conocimientos, tan sólo autoriza su uso, lo que se materializa mediante la entrega de software, horas de consultoría, planos, maquinaria, cintas, entre otros.

c) Arrendamiento de cosas o servicios. Idénticas consideraciones se pueden realizar respecto al arrendamiento de cosas o de servicios. En el contrato de know how tenemos que el cedente no pierde la posibilidad de utilizar la tecnología que transfiere en el contrato y que su obligación no es poner a disposición del arrendatario elementos materiales como bienes muebles, servicios, entre otros, sino la de transmitir una serie de conocimientos técnicos.

\section{CONTRATO DE LEASING}

\section{Notas Previas}

El arrendamiento financiero surge en Estados Unidos en los años cincuenta con el nombre de leasing, término con el que también se le conoce a este contrato. En dicho país se constituyeron las primeras sociedades especializadas para celebrar contratos de leasing y su nacimiento obedeció a necesidades financieras de los arrendatarios que, a través de este medio, obtenían la utilización de bienes sin ser propietarios y con un menor desembolso de fondos. Posteriormente, el éxito de este contrato y de las compañías que se dedicaban a celebrarlo hizo que este tipo de negocios se iniciara en otros países.

Este contrato ha recibido diversas denominaciones: a inicios de 1952 era conocido como leasing en Estados Unidos; credit bail o crédito de arrendamiento en Francia; locación financiera en Argentina; alquiler industrial, crédito arrendamiento o arrendamiento financiero en España, siendo ésta última la denominación más utilizada en los países iberoamericanos y que ha sido adoptada por la legislación peruana.

La expresión leasing es de origen sajón y deriva del verbo to lease (arrendar); por su parte, los contratos referidos al alquiler se denominan renting que deriva de to renting. Ambos términos y sinónimos tuvieron el mismo significado.

Para todo contrato de leasing se supone la presencia de un industrial necesitado de bienes de capital, maquinarias, equipo o de bienes inmuebles, y para ejecutar el contrato tiene que buscar un 
proveedor para determinar qué equipos y en qué condiciones podrían satisfacer las necesidades de su empresa. Ubicada la necesidad y solución entra en contacto con una sociedad especializada la cual procede, en desarrollo del contrato y contra la promesa que el bien será tomado en alquiler, a adquirirlo del proveedor y entregárselo en arrendamiento al industrial por un periodo de tiempo más o menos largo, generalmente vinculado al plazo de amortización fiscal de los bienes y con la posibilidad de continuar el arrendamiento en nuevas condiciones o venderle el bien por un valor que será el residual o muy cercano a él ${ }^{63}$.

\section{Algunos apuntes legislativos del leasing en el Perú}

En el Perú el leasing se inició en 1979 con la promulgación del Decreto Ley N. ${ }^{\circ} 22738^{64}$ que introdujo en su artículo 2 el concepto legal del arrendamiento financiero, permitiendo su uso solo a las empresas financieras que posean maquinarias, equipos y vehículos destinados al arrendamiento financiero.

Como se demuestra, en el Perú fueron inicialmente las empresas financieras las que estaban autorizadas a realizar operaciones de leasing hasta que se promulgó el Decreto Legislativo N. ${ }^{\circ} 212 \mathrm{del}$ 12 de julio de $1981^{65}$ y se amplió la autorización, permitiendo a cualquier otra empresa autorizada por la Superintendencia de Banca y Seguros para operar este tipo de contratos. Ello dio origen a la reglamentación para la constitución de las empresas de arrendamiento financiero, aprobada mediante Decreto Supremo N. ${ }^{\circ}$ 097-82-EFC del 31 de marzo de1982.

Asimismo, por Decreto Legislativo N. ${ }^{\circ} 299^{66}$ del 26 de julio de 1984 se reestructura la normatividad del arrendamiento financiero, permitiendo operar como arrendadoras, además de las empresas financieras, a cualquier otra empresa autorizada por la Superintendencia de Banca y
Seguros como las empresas bancarias. Este paso realmente es más trascendente por cuanto amplía el panorama de las operaciones de leasing a realizarse en el país. El mencionado Decreto Legislativo fue reglamentado por Decreto Supremo N. ${ }^{\circ} 559-84-\mathrm{EFC}^{67}$.

Las operaciones de leasing que empezaron su desarrollo a inicios de los ochenta, como lo demuestra el hecho de que Sogewiese Leasing obtuviera utilidades por el doble de su capital social, alcanzando su más alto índice de crecimiento entre los años de 1983 y 1996, siendo el mayor beneficiado el sector industrial con un $34 \%$ del total de sus transacciones efectuadas, seguido por el sector de comercio con un $28 \%$, y servicios con un $20 \%$. El crecimiento se detuvo en los años siguientes ${ }^{68}$ para luego repuntar en los últimos tres años como producto del auge económico que vive el país.

En la actualidad podemos decir que el ámbito donde más se utiliza este tipo de contrato es en el sector bancario, financiero, la industria manufacturera, y los negocios de maquinarias y equipos para el movimiento de tierras.

\section{Definición}

Por lo expuesto anteriormente, se puede definir el contrato de leasing o arrendamiento financiero en su forma más representativa, como aquel por virtud del cual una sociedad especializada adquiere, a petición de su cliente, determinados bienes que le entrega a título de alquiler, mediante el pago de una remuneración y con la opción para que el arrendatario, al vencimiento del plazo, pueda continuar el contrato en nuevas condiciones o pueda adquirir los bienes en su poder ${ }^{69}$.

Normativamente en el Perú ${ }^{70}$ definen al leasing como un contrato mercantil que tiene por objeto la locación de bienes muebles o inmuebles por una empresa locadora para el uso de la arrendataria,

63 Rodríguez Azuero, Sergio (1990), p. 430.

64 Véase Decreto Ley N. ${ }^{\circ} 22738$ del 23 de octubre de 1979.

65 Véase Decreto Legislativo N. ${ }^{\circ} 212$ del 12 de julio de 1981.

66 Véase Decreto Legislativo N. ${ }^{\circ} 299$ del 26 de julio de 1984.

67 Véase Decreto Supremo N. ${ }^{\circ}$ 559-84-EFC del 28 de diciembre de 1984.

68 Ver Caballero Bustamante/boletines; Revista informativa electrónicos/derecho comercial/leasing o arrendamiento financiero, en http://www.caballerobustamante.com.pe/boletin/boletincomercial34.asp.

69 Véase, Ribó Durán (1998).

70 Véase el Decreto Legislativo N. ${ }^{\circ} 212$ del 12 de junio de 1981 y el Decreto Legislativo N. ${ }^{\circ} 299$ del 26 de julio de 1984 , así como su reglamento Decreto Supremo N. ${ }^{\circ} 559-84-E F C$. 
mediante pago de cuotas periódicas y con opción a favor de la arrendataria de comprar dichos bienes por un valor pactado.

En otras palabras, se puede decir que el contrato de leasing es un contrato de financiamiento en virtud del cual una de las partes, la empresa de leasing, se obliga a adquirir y luego dar en uso un bien de capital elegido previamente por la otra parte, la empresa usuaria, a cambio del pago de un canon como contraprestación por esta, durante un determinado plazo contractual que generalmente coincide con la vida útil del bien financiado. El arrendatario puede ejercer la opción de compra pagando el valor residual pactado, prorrogar o firmar un nuevo contrato o, en su defecto devolver el bien.

\section{Naturaleza jurídica}

Al ser el contrato de leasing un contrato sui generis es un poco difícil identificar en forma absoluta su naturaleza jurídica; sin embargo, es de vital importancia definir su naturaleza para determinar qué normas son aplicables, la manera cómo se forma, las obligaciones que surgen del mismo, la posibilidad de ejercer la opción de compra, entre otros. Ante este escenario es que se han planteado diferentes teorías que podemos mencionar al respecto, tales como:

a) Teoría del arrendamiento. La doctrina, en su mayoría, coincide en que fue una de las primeras teorías, sino la primera, propuesta para explicar la esencia y naturaleza del contrato de leasing.

En el Perú, el anterior Decreto Legislativo N. ${ }^{\circ}$ 212 y el Decreto Legislativo N. ${ }^{\circ} 299$ se refieren al "arrendamiento con opción de compra". En éstos se observa cómo se incorpora la esencia de la relación jurídica entre la empresa de leasing y la usuaria que reside en el cambio entre la atribución temporaria del goce de un bien y el pago de contraprestación, la cual constituye la causa típica del contrato de arrendamiento.

La unidad contractual del arrendamiento no queda desvirtuada por la inclusión de cláusulas que lo conforman como un arrendamiento con finalidad financiera, pues la compra-venta entre el arrendador y el suministrador del bien constituye una relación jurídica separada y distinta del arrendamiento celebrado entre el primero y el usuario-arrendatario. No obstante, la adquisición del bien por sociedad de leasing es determinado directamente por el arrendamiento, ya que se trata de un contrato de ejecución-adquisición del bien, dentro del marco de otro distinto (arrendamiento financiero $)^{71}$.

Quizás una de las limitaciones para regular el leasing como arrendamiento radica en la llamada función financiera del mismo, por cuanto el arrendamiento solo tiene tal función cuando encubre una relación de crédito y de garantía.

Sin embargo, es importante comentar que el leasing y el arrendamiento tienen, un punto en común: la disposición de bienes en calidad de uso. Si nos basamos en la finalidad, función y efectos de cada una de estas instituciones contractuales, encontraremos aspectos que los distancian. Sin embargo, existen otras corrientes doctrinarias ${ }^{72}$ que critican esta postura al considerar al leasing fuera del marco jurídico del arrendamiento; afirman que si bien las formas poseen algunos elementos en común, el leasing enmarca elementos esenciales (término inicial y cláusula de opción de compra), mientras que el arrendamiento carece de los elementos citados y, de faltar éstos, se desvirtúa el carácter económico-financiero de la institución.

b) Teoría de la compra-venta. Quienes sostienen esta teoría afirman "que entre la sociedad de leasing que tranfiere el uso y goce del bien y el usuario - quien lo toma- existe acuerdo en relación al bien y al precio y que la voluntad de las partes es celebrar una compra venta a plazos".

Según esta tendencia, se fortalece el criterio de la circunstancia de que la suma de los alquileres que el usuario debe satisfacer sobrepasa el valor del material nuevo facilitado y proporciona, además, un beneficio a la sociedad de leasing. Asimismo, consideran que la opción de compra a favor del usuario, que es esencial en este contrato, es otro de los argumentos para calificarlo como compra-venta. Los tratadistas que se oponen a esta teoría sostienen que el contrato de arrendamiento financiero transfiere el uso del bien, mientras que la compraventa transfiere la propiedad del mismo. En el

71 Ver Vera Paredes, Isaías. (2002).

72 Ver Barreira, Delfino. (1978), y Buonocore, Vicenzo. (1990). 
contrato de arrendamiento no existe desde el principio la voluntad de comprar.

c) Teoría del préstamo. El préstamo está regulado mediante dos figuras contractuales que son el mutuo o préstamo de consumo y el préstamo de uso.

Por el mutuo, el mutuante se obliga a entregar al mutuario una determinada cantidad de dinero o de bienes consumibles a cambio de que se devuelvan otros de la misma especie, calidad o cantidad. El arrendamiento financiero de dinero no es posible de esta manera porque éste no es un bien identificable y en cuanto a los bienes consumibles, aun en el supuesto de que pudiesen ser identificados, dicha identificación resulta irrelevante por cuanto en el mutuo, el mutuatario está obligado solamente a devolver otros bienes de la misma especie, calidad o cantidad pero no los mismos. En cambio, en el arrendamiento financiero, si no se ejercita la opción de compra al término del plazo se deberá devolver el producto.

El comodato es un contrato cuya esencia es la gratuidad, por medio del cual el comodante se obliga a entregar gratuitamente al comodatario un bien no consumible para que lo use por cierto tiempo o para un fin y luego lo devuelva; en cambio, el contrato de arrendamiento financiero se caracteriza por ser oneroso.

d) Teoría de la gestión de negocios. Es un acto jurídico unilateral que se presenta cuando alguien, sin estar obligado ni facultado para ello, asume conscientemente el manejo de los negocios o la administración de los bienes de otro que lo ignora, en beneficio de este. La gestión surge, por consiguiente, de un acto unilateral de voluntad del gestor que asume en forma espontánea la gestión de los negocios, o la administración de los bienes de otro ${ }^{73}$. El contrato de arrendamiento financiero es un acuerdo de voluntades entre dos partes: la empresa locadora y la arrendataria; por ende, existen contraprestaciones sinalagmáticas.

e) Teoría del mandato. La figura del mandato no se presenta si no existe una oferta del cliente, en virtud del cual si las empresas leasing adquieren el bien que este desea, se obliga a arrendarlo por un tiempo determinado, con todos aquellos otros acuerdos y condiciones que son generales en estos contratos. Algunos autores consideran que el mandante es la arrendataria y el mandatario la empresa locadora porque efectúa la compra del bien de acuerdo con las instrucciones impartidas por la primera. A criterio de otros autores ${ }^{74}$, consideran que el leasing no es mandato, puesto que ambas figuras contienen elementos diferentes, ídem fines distintos; además, es de señalar que la teoría del mandato es inaplicable al leasing por las siguientes razones:

- Para aceptar la tesis del mandato es necesario aceptar que el usuario actúa en interés o por cuenta de la sociedad de leasing; sin embargo, el usuario actúa en su propio interés al elegir el proveedor y determinar las condiciones de los bienes.

- El usuario no concluye el contrato de compra-venta con el proveedor, ni el proveedor se obliga a entregar el bien, ni la sociedad de leasing a pagar el precio mientras éste no le haga llegar su consentimiento expresado formalmente en un pedido y orden de compra.

- El mandato se formaliza en la primera convención; sin embargo, vemos que allí no se determina ni el bien ni el precio. Es dudoso, pues, que exista un mandato en el que el mandatario no reciba ninguna instrucción del mandante.

\section{Características generales del contrato de leasing}

- El bien es adquirido por una empresa financiera de leasing basándose en las especificaciones del usuario.

- La duración de la operación no siempre coincide con la vida útil del bien. Asimismo, el contrato no puede ser rescindido de forma unilateral por parte del usuario antes de la finalización del período de arrendamiento acordado.

- Los pagos que periódicamente hiciera el usuario deben ser capaces de amortizar la totalidad de la inversión. Estos pagos deberán ser suficientes para cubrir, además del costo del bien, los gastos de financiación y explotación de la

73 Ver Cárdenas Quiroz, Carlos. (2002). p. 751.

74 Véase Guisado Tato, Manuel. (1986), y Belkaoui, Amhed. (1983). 
entidad financiera, así como los beneficios empresariales.

- El tipo de interés pactado podrá ser fijo o variable.

- La sociedad de leasing no impone al cliente ninguna limitación en el uso del bien financiado, excepto la de su correcta utilización.

- Los impuestos, tasas y otros gastos, actuales o futuros, surgidos como consecuencia del arrendamiento financiero están a cargo del cliente aunque esto deberá constar en una cláusula del contrato.

- Al concluir la operación, el usuario tiene la alternativa de adquirir el bien por el que pagará el mismo monto de la opción de compra. Este valor deberá constar expresamente entre las condiciones del contrato del leasing.

\section{Características del contrato de arrendamiento financiero}

Entre las características esenciales de este contrato y que lo diferencian de las otras modalidades de contratos de acuerdo al Decreto Legislativo N. ${ }^{\circ}$ $299^{75}$, artículo 1 , tenemos que en el contrato de leasing los caracteres principales se encuentran en la naturaleza de su composición, en el contenido de las prestaciones asumidas por cada una de las partes y en la forma cómo se obtiene el cumplimiento de las mismas. En esa orientación podemos decir que el leasing es un contrato:

a) Típico. La clasificación de los contratos en típicos y atípicos viene desde el derecho romano y se ha dado en todos los países con legislación positiva vigente; no obstante, no tiene la misma importancia ni sentido en el derecho moderno lo que antes sí tenía en el derecho romano.

El leasing, como institución financiera en los países que tiene presencia como el Perú, viene a ser un contrato típico, ya que el derecho positivo, luego de individualizar el leasing a través de una serie de elementos y datos peculiares, lo ha valorado y le ha atribuido una concreta regulación: primero, el Decreto Legislativo N. ${ }^{\circ}$ 212 y después el Decreto Legislativo N. 299. Debemos subrayar que el legislador al redactar este dispositivo, como ya es habitual ante la aparición de nuevas instituciones contractuales, se ha preocupado más de los aspectos tributarios y financieros que del aspecto sustancial.

b) Principal. Un contrato es principal cuando cumple, por sí mismo, un fin contractual propio y subsistente, sin relación necesaria con ningún otro contrato; es decir, no depende ni lógica ni jurídicamente de otro pues él se presenta independiente de aquél.

En vía de ejemplo son contratos principales todos los que figuran en la Sección Segunda del Libro VII del Código Civil de 1984, con excepción de la fianza que es accesoria, los de los Libros II y III del Código de Comercio, claro está, los que aún permanecen en su seno como los contratos de transporte y de fletamento.

Nuestro ordenamiento jurídico positivo, y en su momento la doctrina mayoritaria, denominan al leasing como contrato principal porque tiene vida propia, y es independiente lógica y jurídicamente de cualquier otro contrato. Sin embargo, algunos contratos como el de compra-venta, seguros y otros, a pesar de tener la orientación de principal, tienen en el leasing la de accesorios.

c) Consensual. En su rol de financiamiento al servicio de la empresa en la búsqueda de contribuir con su competitividad, su consensualidad es declarada como se desprende del artículo 8 del Decreto Legislativo N. ${ }^{\circ} 299$ cuando señala que "el contrato de arrendamiento financiero se celebrará mediante escritura pública..."; en ese sentido se interpreta que la voluntad contractual genera efectos en el contrato y en su contenido.

d) Oneroso. Son onerosos aquellos contratos en los cuales cada una de las partes sufre un sacrificio (empobrecimiento) patrimonial con la intención de procurarse una correspondiente ventaja: percibir una atribución patrimonial, o un enriquecimiento proporcional, como contraprestación. Son gratuitos (o lucrativos, di lucro, o de beneficencia) aquellos en los cuales una sola de las partes recibe una ventaja patrimonial, o lucro (atribución patrimonial), y la otra solo soporta el sacrificio.

75 Véase Decreto Legislativo №299 del 29 de julio de 1984. 
En el contrato de leasing, el sacrificio patrimonial que experimenta la empresa financiera al adquirir el bien y conceder el uso del mismo durante un plazo inicial se ve compensado con el pago del canon periódico que recibe y, en su oportunidad, por el pago del valor residual pactado para la ulterior transferencia de la propiedad del bien. A su turno, en la empresa usuaria surge un sacrificio patrimonial al tener que pagar los respectivos cánones, pero se beneficia con el uso, disfrute y, a su sola decisión, con la propiedad del bien que ha sido materia del contrato.

e) Conmutativo. Porque en el mismo acto de celebración del contrato ambas partes tienen conocimiento del aporte económico y las ventajas del contrato, por eso se dice que cada parte conoce con la debida anticipación cuál es la importancia económica que el contrato reviste para ellas.

f) De duración. El contrato de leasing es de duración en un determinado tiempo, ya que las prestaciones de la empresa de leasing y de la usuaria se van ejecutando en el tiempo que puede ser prolongado para que el leasing produzca el efecto que ambas partes buscan, es decir, este es un contrato de duración determinada, donde la prestación de la empresa de leasing es continuada y la contraprestación de la usuaria es periódica.

g) Es un contrato mercantil. Porque así lo determina la legislación especial, aunque su naturaleza como tal es discutible. Coincidiendo con muchos autores que indican que:

... no es fácil justificar desde el punto de vista legislativo la distinción entre contrato mercantil y contrato civil. Al final el concepto de contrato mercantil vuelve a plantear el concepto de acto de comercio y la distinción entre acto de comercio y acto civil. Es el conocido el criterio de la calificación automática ${ }^{76}$.

Sin embargo, otros autores ${ }^{77}$ encuentran caracteres que ayudan a delimitar sus características, entre estas podemos citar:

- Que es una acción de financiación ejecutada por empresas especializadas.

- La empresa cliente, al no hacer desembolsos iniciales importantes, mantiene actualizada su infraestructura con mayor productividad y sin incremento de sus activos fijos.

- La entidad financiera adquiere el bien que ha de ser arrendado, retiene su propiedad y facilita su uso y goce.

- La selección del bien y de la firma proveedora queda a cargo del cliente.

- El equipo solicitado comienza a producir y a rendir beneficios inmediatamente luego de su entrega, la que se materializa con el pago de la primera cuota del leasing.

- Se otorga la posibilidad de adquirir el bien al vencimiento del contrato mediante el pago de un valor residual fijo preestablecido que, en ese momento, puede resultar sumamente ventajoso.

- Los períodos de la operación del leasing se determinan habitualmente en base al tiempo útil del bien.

\section{Partes integrantes del contrato de leasing}

Podemos mencionar en este contrato los siguientes:

a) Arrendatario o usuario. Es el industrial, cliente que va a ser de la sociedad de leasing, quien asegura el aspecto técnico de la operación que, como sabemos, generalmente identifica y determina sus necesidades, y escoge el proveedor y la clase de maquinaria o equipos que necesite. En ese sentido, es él y no la sociedad de leasing quien da su conformidad sobre la calidad y funcionamiento de los bienes al momento de su entrega.

b) Sociedades de leasing. Su objetivo principal es asegurar el soporte financiero y con esta intervención establece la posibilidad de aportar recursos financieros para adquirir los bienes objeto de la operación.

c) Proveedor. Su participación es secundaria en relación con el contrato del leasing financiero. Sin embargo, es de señalar que en algunas oportunidades tiene iniciativa con el objeto de promocionar o presentar sus ventas y de esa manera podría participar en el contrato si suscribe y se obliga en lugar del arrendador a entregar el bien, garantizar su funcionamiento, efectuar las reparaciones a que haya lugar, entre otros, como es cada vez más usual.

76 Garrigues, Joaquín. (1979), p. 12.

77 Véase al respecto Belkaoui, Amhed. (1983); Villacorta Cavero, Armando. (2001), y Guisado Tato, Manuel. (1986). 


\section{Clasificación del leasing}

Por sus características peculiares y en función a las operaciones desarrolladas, el leasing se clasifica de acuerdo a las siguientes nociones ${ }^{78}$ :

- Por su finalidad: leasing operativo y financiero.

- Por su ejecución: leasing directo e indirecto.

- Por el objeto: leasing mobiliario e inmobiliario.

- Por el ámbito territorial de aplicación: leasing nacional e internacional.

Veamos cada una de estas modalidades de clasificación del leasing.

a) Por su finalidad ${ }^{79}$.

- Leasing financiero. Es el más utilizado en nuestro país, respondiendo a la modalidad de entrega de bienes. Entre sus características tenemos:

- La finalidad de esta operación es la compra de un bien, tomando el leasing como una alternativa más frente al resto de opciones de financiamiento.

- El contrato es irrevocable, salvo pacto en contrario.

- La duración suele ser a largo plazo, entre dos a cinco años para bienes muebles y entre 10 a 15 años para bienes inmuebles.

- La opción de compra es baja. Suele coincidir con el valor de una cuota, cubriendo las cuotas que paga el cliente la totalidad del valor del activo.

- Todos los gastos de mantenimiento, seguros, operación, reparación, etc., corren por cuenta del cliente.

- La obsolescencia del bien la soporta el arrendatario, ya que el bien pasa a ser de su propiedad al final del contrato.

- Esta operación enmarca una nueva modalidad de financiamiento, por lo que solo puede ser prestada por entidades bancarias o instituciones financieras puesto que éstas son las únicas entidades autorizadas a realizar mediación entre la oferta y la demanda pública de recursos financieros ${ }^{80}$.

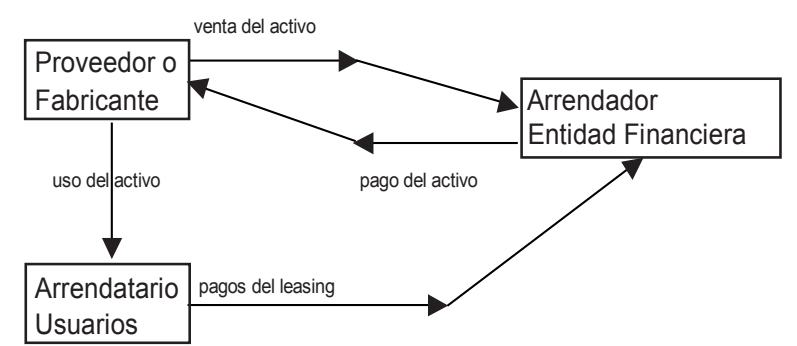

- Leasing operativo. Este tipo de operación se caracteriza ${ }^{81}$ porque se cede el uso de un determinado bien y equipo contra el pago de unas cuotas de arrendamiento periódicas, que comprenden tanto la amortización como los intereses de financiación, así como los gastos de mantenimiento y reparación.

Entre sus características tenemos:

- El propio vendedor es el que se encarga de gestionar el arrendamiento.

- Se encarga además del mantenimiento y de los contactos que le permitan garantizar el servicio técnico a sus clientes.

- El usuario se desentiende del mantenimiento del bien, aunque se limitará su utilización a un determinado número de horas de trabajo ordinario.

- La duración de la operación suele ser de corto y mediano plazo.

- El arrendamiento puede ser revocado por el arrendatario transcurrido un determinado plazo de tiempo (24 meses) sin más que precisar la anticipación. Se elimina para el arrendatario, por tanto, el riesgo de obsolescencia del bien.

- Al finalizar la operación el arrendador tiene la opción de comprar el bien o de devolverlo al arrendador. En este tipo de operaciones el valor residual suele ser alto.

\begin{tabular}{|l|c|l|}
\hline $\begin{array}{l}\text { Proveedor o } \\
\text { Fabricante }\end{array}$ & Usos del activo & $\begin{array}{l}\text { Arrendatario } \\
\text { Usuarios }\end{array}$ \\
\cline { 2 - 3 } & & \\
\end{tabular}

- Diferencias relevantes entre el leasing operativo y el leasing financiero. El leasing financiero se diferencia y distingue del leasing operativo en los aspectos siguientes:

78 Véase al respecto Bravo Melgar, Sidney (1997), pp. 168 y ss.

79 Bierman, Harold y Smidt, Seymour (1980).

80 Al respecto véase Escobar Solar, Antonio (1984).

81 Ver Belkaoui, Amhed. (1983), op.cit.; Guisado Tato, Manuel (1986), pp. 263-271. 


\begin{tabular}{|l|l|}
\hline \multicolumn{1}{|c|}{ Leasing financiero } & \multicolumn{1}{|c|}{ Leasing operativo } \\
\hline $\begin{array}{l}\text { El arrendador es la empresa financiera o filiales } \\
\text { de bancos. }\end{array}$ & $\begin{array}{l}\text { Son arrendadores los fabricantes, distribuidores } \\
\text { o importadores de bienes de equipo. }\end{array}$ \\
\hline $\begin{array}{l}\text { Los bienes son de carácter especializado y } \\
\text { generalmente son bienes de mercado restringido. }\end{array}$ & $\begin{array}{l}\text { El bien es de tipo estándar y de obsolescencia } \\
\text { rauda. }\end{array}$ \\
\hline $\begin{array}{l}\text { El plazo del contrato es de tres a cinco años si } \\
\text { se trata de bienes muebles y de } 20 \text { a } 30 \text { años si } \\
\text { se trata de bienes inmuebles. }\end{array}$ & $\begin{array}{l}\text { El plazo del contrato es corto, normalmente de } \\
\text { uno a tres años. }\end{array}$ \\
\hline $\begin{array}{l}\text { La arrendataria no tiene facultad de resolver uni- } \\
\text { lateralmente el contrato cuando las condiciones } \\
\text { técnicas no le son satisfactorias. El contrato es } \\
\text { irrevocable para ambos contratantes. }\end{array}$ & $\begin{array}{l}\text { El contrato es revocable por el arrendatario con } \\
\text { preaviso. }\end{array}$ \\
\hline $\begin{array}{l}\text { Los gastos de conservación y mantenimiento del } \\
\text { material están a cargo del arrendatario. }\end{array}$ & $\begin{array}{l}\text { El arrendador está obligado al mantenimiento } \\
\text { del bien, pago de los servicios, etc. }\end{array}$ \\
\hline $\begin{array}{l}\text { El arrendador asume los riesgos financieros y el } \\
\text { arrendatario, los riesgos técnicos. }\end{array}$ & $\begin{array}{l}\text { El arrendador asume los riesgos técnicos y } \\
\text { financieros. El arrendatario no asume riesgo } \\
\text { alguno. }\end{array}$ \\
\hline $\begin{array}{l}\text { Tiene por finalidad ofrecer una técnica de fi- } \\
\text { nanciación. }\end{array}$ & Ofrece un servicio. \\
\hline
\end{tabular}

\section{b) Por la ejecución}

- Leasing directo. Es directo cuando se celebra entre el cliente que quiere ser usuario de un bien de particularidades especiales y el que adquiere de un proveedor el bien a petición directa del cliente y lo da luego en arrendamiento por medio de la celebración del contrato de leasing. Es decir, el leasing directo es aquel que se celebra, por una parte, entre el cliente que desea ser usuario de un bien de características especiales y la empresa de leasing ${ }^{82}$ por la otra, que adquiere de un proveedor el bien a petición expresa del cliente y lo da posteriormente en arrendamiento, mediante la celebración del contrato de leasing respectivo. Esta modalidad mayormente se da en los casos de adquisición de equipos industrializados.

- Leasing indirecto. Es indirecto cuando el fabricante de una empresa llega a un acuerdo con la empresa de leasing para que financie a los usuarios respaldando el fabricante la operación con la garantía del servicio técnico y de reposición del bien si este producto no está en condiciones o es muy utilizado por los fabricantes de productos. Esta modalidad de leasing es muy utilizada para colocar productos en el mercado. c) Por el objeto:

- Leasing mobiliario. Esta modalidad se da en los bienes muebles y se distinguen por la operación y el monto del contrato. Si es de poca cuantía mayormente se utiliza un documento privado simple al que se le anexa un pagaré con autorización del notario para los fines de contar con un título ejecutivo; si el monto es mayor se realiza mediante escritura pública.

- Leasing inmobiliario. Esta modalidad se enmarcaría dentro del artículo 885 del Código Civil peruano. El objeto del arrendamiento es un inmueble destinado a actividades productivas, excluidas las viviendas. La sociedad de leasing se limita a adquirir el inmueble a financiar su construcción a solicitud de su cliente y de acuerdo con sus indicaciones. El arrendatario es quien elige el inmueble y pacta las condiciones de compra-venta.

Las operaciones se suelen concretar a largo plazo. Este tipo de operaciones suelen ser de tipo leasing financiero pues el arrendatario se compromete al inicio de la operación a ejercitar la opción de compra cuando finalice el contrato.

d) Por el ámbito territorial. Mencionamos esta clase de leasing para destacar la tendencia a ex-

82 Ver Leyva Saavedra, José (1977) y Trelles Araujo, Gustavo, “Publicación sobre el leasing”. En línea: www.gestiopolis.en/www. gestiopolis.com/recursos/documentos/fulldocs/fin1/elleasing.htm 
plotar las posibilidades derivadas del llamado leasing internacional o 'cross border leasing; es decir, aquel en el cual la sociedad de leasing y el arrendatario se encuentran bajo la jurisdicción de legislaciones nacionales diferentes.

\section{Ventajas y desventajas}

Los diferentes autores señalan que uno de los temas que ha merecido atención en la doctrina ${ }^{83}$ es el de las ventajas e inconvenientes que ofrece este medio de financiamiento. Así, para resolver los muchos problemas jurídicos que plantea el leasing, tanto la doctrina como la jurisprudencia han tenido presentes las ventajas que proporciona esta institución a las empresas usuarias.

a) Ventajas del leasing. El leasing ofrece muchas ventajas que hacen atractivo su empleo. Sus aspectos positivos son mayores -tanto en números como en importancia- que los factores negativos. Entre las principales ventajas que presenta el leasing tenemos las siguientes:

- Nueva técnica de financiamiento. El leasing permite obtener financiamiento por la totalidad del valor de adquisición del bien seleccionado, sin deducciones o reducciones de ninguna naturaleza. Esta característica lo configura como un contrato ventajoso si efectuamos la comparación con otros medios de financiamiento, en los cuales la asistencia crediticia se limita a una porción del valor necesitado, debiendo el deudor sufragar el saldo restante con fondos propios.

- Acceso a otras fuentes crediticias. El leasing en nada afecta las posibilidades de recurrir a otras fuentes de crédito. Mientras que los préstamos ortodoxos deben reflejarse en el activo y en el pasivo del balance de la empresa tomadora, el leasing no aparece consignado en ninguno de sus rubros. Esta neutralidad de orden contable deja prácticamente intactas las posibilidades de endeudamiento del tomador.

- Inexistencia de inversiones iniciales. En la contratación del leasing el tomador no hace desembolsos iniciales de envergadura. Sólo abona la primera cuota pactada y todos aquellos gastos de sellados, impuestos, seguros, etc., relativos al bien que es faci- litado en uso. No existen anticipos, saldos compensatorios ni pagos parciales. Esta circunstancia viabiliza al tomador mantener actualizada su infraestructura con mayor productividad sin incremento de los activos fijos.

- Eliminación de los riesgos de obsolescencia. El leasing facilita el progreso en materia de equipamiento. A través de él la empresa puede emprender la renovación de sus equipos de modo más ventajoso que el que emplearía recurriendo a otros sistemas tradicionales. A través del leasing el tomador puede equiparse procurando el material más adecuado y que responda mejor a sus necesidades y, en la medida que prescinda de los equipos obsoletos, podrá sustituirlos por los nuevos que aparezcan en el mercado.

- Incremento de la capacidad de producción. El leasing favorece el incremento de los medios de producción, especialmente del parque de bienes de equipo y maquinaria industrial en general. El empleo del leasing conduce al empresario a incrementar el volumen de sus medios de producción; esto permitirá que el equipamiento o renovación contratada incremente la capacidad de producción de la empresa.

- Optimización de la productividad del capital. Uno de los más poderosos factores de la productividad del capital es la innovación y renovación técnica de los equipos originarios, por lo que se infiere que el leasing coadyuva a la optimización de la productividad, constituyéndose en una eficaz herramienta en contra de la obsolescencia.

- Simplificación del control de costos. El leasing permite la efectivización de un control estricto de sus propios costos operativos, en relación con otras modalidades de financiamiento. Ello es evidente en virtud del carácter fijo e inamovible que generalmente reviste el precio del leasing.

- Flexibilidad operativa. El financiamiento a través del leasing es adaptable a las específicas necesidades del tomador. Esta flexibilidad de adaptación puede enmarcar diferentes aspectos como exigencias de

83 Al respecto ver Leyva, José. (1995); Barreira, Delfino. (1978) y Buonocore, Vicenzo. (1990). 
la producción, plazos de financiamiento, sustitución por obsolescencia, modalidades contractuales, limitaciones presupuestales, entre otros.

b) Desventajas del leasing. Entre las principales desventajas que configura el leasing tenemos:

- Determinación del precio. El costo del leasing es superior respecto de los otros sistemas ortodoxos de financiación.

- Fluidez de las innovaciones tecnológicas. La fluidez del cambio tecnológico puede incidir desfavorablemente para el dador como para el tomador, en mérito a las estipulaciones contractuales convenidas y suscritas.

- Asunción de los riesgos del bien. El riesgo por depreciación o envejecimiento técnico y económico del bien contratado es el inconveniente más grave que asumen las partes contratantes.

- La duración económica de un bien es insegura. Ello en virtud de estar constantemente expuesta a los efectos de las innovaciones tecnológicas. Esta inseguridad se acrecienta en los casos de equipos de alto costo.

\section{CONTRATO DE ESPECTÁCULO}

Es aquel que se celebra entre el organizador de un espectáculo público y el público asistente, por medio del cual el primero se compromete a exhibir un espectáculo, proveyendo al público un lugar y comodidades necesarias para poder presenciarlo, a cambio de un precio en dinero.

\section{Características}

- Bilateral. Ya que el contrato genera derechos y obligaciones para las partes que suscriben el contrato.

- Oneroso. Cada una de las partes obtiene una ventaja de su prestación.

- Consensual. Que se perfecciona con el consentimiento de las partes.

- No formal. No se exige ninguna forma específica de cómo debe ser instrumentado.

- Atípico. No se encuentra regulado en nuestro ordenamiento jurídico por lo que se le denomina contrato innominado.

\section{Obligaciones del empresario}

- Cumplir reglamentaciones (acatar medidas de seguridad e higiene del local, sistemas de seguridad contra incendios, iluminación apropiada, ventilación suficiente).

- Cumplir con la programación del modo en que fue anunciada.

- Proveer al espectador de un lugar con visibilidad adecuada y, en su caso, con la reserva de su butaca.

- Responsabilizarse por la pérdida o sustracción de efectos depositados en guardarropas.

- Vigilar y controlar a los espectadores, impidiendo el ingreso o permanencia de quienes perturben el orden y normal desarrollo del espectáculo, además de controlar los desórdenes ocasionados por la policía o los empleados.

\section{Obligaciones del espectador}

- Pagar el precio fijado para la entrada.

- Observar un comportamiento apropiado a fin de no producir daño a los demás asistentes ni a las instalaciones del lugar.

4. Responsabilidad de los organizadores frente al público

- Obligación táctica de seguridad.

- Garantizar al espectador que con motivo de la realización del espectáculo no sufrirá daño alguno ni en su persona ni en sus bienes.

- La responsabilidad es objetiva y tiene apoyo en la teoría del riesgo y del aprovechamiento económico. Con tales actividades los empresarios crean riesgos para terceros, por lo que es lógico que deban asumir la responsabilidad que esos riesgos generen.

\section{Régimen legal para la violencia en espectáculos} deportivos

La ley consagra:

- Responsabilidad objetiva por el riesgo creado por las entidades o asociaciones participantes en competencias futbolísticas respecto del espectador, quienes responden en forma solidaria por los ilícitos cometidos en los estadios sino media culpa del damnificado. 
- En caso de responsabilidad colectiva como el disparo de un arma de fuego desde una multitud que hiere a un espectador. La jurisprudencia mayoritaria coincide en que la acción de otros espectadores no puede considerarse hecho de terceros ni lo convierte en caso fortuito ya que la admisión masiva de estos espectadores crea el riesgo, y el organizador debe responder por ellos desde el momento en que permite su ingreso, por tener a su cargo la seguridad del espectador.

- Ámbito de aplicación. Cuando se cometan con motivo o en ocasión de un espectáculo deportivo en el ámbito de concurrencia pública o en sus inmediaciones, antes o después de él. Un espectador damnificado puede presentar como prueba que el daño sufrido ha sido a causa del desarrollo del espectáculo, debiendo haber relación de causalidad entre la actividad deportiva y el daño.

- Eximientes de responsabilidad. El empresario, para liberarse de responsabilidad, debe probar culpa de la víctima en caso fortuito o de fuerza mayor externos como por ejemplo un disparo proveniente de un edificio vecino. La responsabilidad puede ir contra los organizadores del evento y contra el autor material del hecho, así como también contra el dueño de las instalaciones donde la competencia deportiva es desarrollada, por el daño causado por las cosas de su propiedad o por las que estén bajo su guarda; por ejemplo, el derrumbe de las tribunas.

- En caso de responsabilidad concurrente. Responden todos los que participaron en el hecho o integren el grupo donde se originó el perjuicio.

- Damnificado. Podrá ofrecer una filmación realizada por la autoridad competente.

- Responsabilidad del empresario. El empresario es civilmente responsable por los daños causados a los asistentes cuando en función del poder de policía que le corresponde, omite o ejerce inadecuadamente alguna de las actividades que le son impuestas por insuficiente control en cuanto:

- Al poder de policía municipal (control de construcciones).

- Al poder de policía deportiva (control de instalaciones o cosas destinadas al funcionamiento del espectáculo).
- Al poder de policía de seguridad (mantener el orden y tranquilidad de asistentes).

- Responsabilidad frente a los terceros damnificados. Se refiere al daño sufrido por un tercero no espectador, causado por un deportista, donde el organizador responde si media relación de dependencia entre este y el jugador.

\section{CONTRATO INFORMÁTICO}

\section{Notas previas sobre los contratos informáticos}

Los contratos informáticos tienen un tratamiento jurídico sui géneris. Tienen características peculiares, emergentes del mercado internacional de tecnología informática; por ende, su regulación supera las normas reguladoras de los contratos civiles y comerciales específicamente.

En muchos países latinoamericanos tales como Venezuela, Guatemala, México y Argentina, las autoridades competentes para el control de las adquisiciones públicas de hardware y software elaboraron contratos tipo o cláusulas modelo para regir las relaciones de las entidades del Gobierno $\mathrm{y}$, en algunos casos, empresas estatales con los proveedores. En el caso de México y Venezuela, dichos contratos han sido objeto de asiduas revisiones a fin de perfeccionarlos y adecuarlos a los emergentes por el avance tecnológico. Se han tratado de simplificar las cláusulas correspondientes a test de aceptación, garantías y a viabilizar otros tópicos.

La tutela del software ha sido optada por la mayor parte de los países industrializados, en el marco del derecho de autor. En Brasil se emitió una ley especial (Ley $\mathrm{N}^{\circ} 7646$ del 18 de diciembre de 1987). Esta ley enmarca el derecho de autor, tratando de integrar el régimen de protección con una normatividad detallada sobre la comercialización de los programas de computación, en especial los de origen extranjero.

El contrato informático es nominado y atípico por no contar con una normatividad y regulación propia, y queda sujeto a la legislación estipulada en el Código Civil.

\section{Definición}

Son aquellos que establecen relaciones jurídicas respecto de prestaciones consistentes en 
trasferir la propiedad, el uso o goce de bienes, $o$ prestar algún servicio, ambos informáticos.

\section{Objeto}

Es la operación jurídica por la cual se crean, modifican, trasmiten o extinguen relaciones obligacionales sobre bienes y servicios informáticos. Estos bienes y servicios se integran por lo general en un sistema que es el conjunto de elementos materiales o inmateriales vinculados por un objetivo común.

\section{Componentes}

- El hardware (duro). Elemento material, herramientas o máquinas (como la consola o pantalla).

- El software (blando). Elemento inmaterial, aquello que no se ve pero hace el funcionamiento del sistema (como los programas).

- Otros. Elemento humano, documentación (como manuales, certificados), asistencia técnica.

\section{Características}

- Complejo. Por la naturaleza de sus elementos y por la diversidad de objetos.

- Condiciones de compatibilidad. Es la posibilidad de que aquello que se vaya a adquirir sea compatible con lo que ya existe en manos del cliente o usuario.

- Modularidad. Que permite que ahora se contrate y en un futuro sea posible de modificarse para ampliarlo o restringirlo, según las necesidades del cliente.

\section{Obligaciones}

a) Del proveedor. Información y consejo a su cliente; informar y advertir al cliente sobre calidad, prestaciones, rendimiento, riesgos, ventajas, etc., de lo que va a adquirir. Debe aconsejar en la correcta elección de los equipos, programas, accesorios (teniendo como principio la buena fe). A mayores sean los conocimientos técnicos del cliente, menor será la responsabilidad del proveedor de bienes y servicios informáticos.

b) Del usuario. Informarse e informar claramente al proveedor sus necesidades informáticas, colaborar diligentemente para precisarlas. c) Concepto de entrega de la cosa. En este contrato la tradición es la entrega que una parte hace a otra, quien la recibe voluntariamente, ambos como consecuencia del cumplimiento de un contrato que puede ser compra-venta o locación. En estos contratos la entrega va más allá de la simple tradición por lo que será necesario establecer plazo de entrega; es decir, un lapso durante el cual el sistema será probado y comprobado su funcionamiento (tiempo luego del cual recién se podrá decir que aquel ha sido entregado). Además, la entrega incluirá la instalación, conexión y puesta en marcha; en ese sentido, como ejemplo de estos contratos, tenemos la compra-venta, leasing de equipos, mantenimiento de sistemas, consultoría de software, entre otros.

\section{BIBLIOGRAFÍA}

\section{Libros}

ALONSO, MARIANO (2003). La Franquicia de la A a la Z. Manual para el Franquiciador y el Franquiciado. Barcelona,Editorial LID.

ALTERINE, ATILIO Y LÓPEZ CABANA, ROBERTO (1989). La autonomía de la voluntad en el contrato moderno. Buenos Aires, AbeledoPerrot.

ANTONORSI, MARCEL (1989). "Ciencia, tecnología y técnica: Ensayo esquemático de definición conceptual”. Citado por GARCÍA, L. (1989). Política e innovación tecnológica: Perspectiva económicas. Madrid, Editorial Monte Ávila.

ARIAS SCHEREIBER PEZET, MAX (1984). Exégesis del Código Civil Peruano de 1984. Lima, Gaceta Jurídica.

ARRUBLA PÁUCAR, JAIME ALBERTO (1997). Contratos Mercantiles. Octava Edición. Tomo I. Lima, Editorial Dike.

ASENSIO, PEDRO (1995). Contratos internacionales sobre propiedad industrial. Madrid, Editorial Civitas. Tomo IV. Buenos Aires, Omeba.

BARREIRA, DELFINO (1978). Leasing. Buenos Aires, Editorial Cangallo.

BAYLOS C., HERMENEGILDO (1993). Tratado de Derecho Industrial. Segunda Edición. Madrid, Editorial Civitas.

BELKAOUI, AMHED (1983). Cost Accounting a Multidimensional Emphasis. New York, The Dryden Press. 
BIERMAN, HAROLD \& SMIDT, SEYMOUR. (1980). The Capital Budgeting Decisión. Quinta Edición. New York, MacMillan Publising Co.

BLANCO J., Araceli (1999). Protección jurídica de las invenciones universitarias y laborales. Pamplona, Aranzadi Editorial.

BORGES B., DENIS (1988). "El comercio de tecnología: aspectos jurídicos, transferencia, licencia y know how". En Revista de Derecho Industrial. Año 10, 1988. Buenos Aires, Ediciones Depalma.

BRAVO MELGAR, SYDNEY (1997). Contratos Modernos Empresariales. Tomo I. Lima, Editora FECAT.

BREUER M., CARLOS (1957). Tratado de patentes de invención. Volumen 1. Buenos Aires, Abeledo-Perrot.

BUNGE, MARIO (1997). La Investigación científica. Capítulo II. Barcelona, Editorial Ariel.

BUONOCORE, VICENZO (1990). Leasing. Aspectos Privatísticos y Tributarios. Buenos Aires, Editorial Abeledo Perrot.

CÁRDENAS QUIROZ, CARLOS (2002). Exposición de motivos y comentarios del Código Civil. Parte III, Vol. VI. Barcelona, Edit. Bosh.

CELI ARÉVALO, MARCO (1978). “Contratos comerciales. El Contrato de Joint Venture en la doctrina, Legislación Peruana y comparada”. En: Revista Jurídica (1993). Trujillo, Industria Gráfica $\mathrm{ABC}$.

CELI ARÉVALO, MARCO (2008). El contrato de Franchising. Análisis Doctrinario. Trujillo, Industria gráfica $\mathrm{ABC}$.

CHULIÁ VICENT, EDUARDO y BELTRÁN ALANDETE, TERESA (1989). Aspectos Jurídicos de los Contratos Atípicos. Cuarta edición. Barcelona, J.M. Bosch Editor.

COGORNO, EDUARDO (1979). Teoría y Técnica de los nuevos contratos comerciales. Buenos Aires, Merú.

COMITÉ BELGA DE DISTRIBUCIÓN (1997). Franchising, una revolución comercial. Barcelona, Editorial Hispano- Europea.

DÍAZ VELAZCO, MANUEL (1987). Estudios sobre propiedad industrial. Barcelona, Grupo español de la AIIPI.

DIRECCIÓN GENERAL DE COMERCIO INTERIOR (1988). La franquicia, una fórmula con futuro.
Madrid, Editorial Ministerio de Economía y Hacienda.

ESCOBAR SOLAR, ANTONIO (1984). El Contrato de Leasing financiero. Madrid, Editorial Civitas.

GARCÍA L., HUMBERTO (1989). Política e innovación tecnológica: perspectivas económicas. Madrid, Monte Ávila Editores.

GARCÍA, MARÍA (2000) Enciclopedia Hispánica. Tomo 4, letra C. Madrid, Colex.

GARRIGUES, JOAQUÍN (1979). Curso de Derecho Mercantil. Lima, Editorial San Marcos.

GÓMEZ SEGADE, J. A. (1981). Algunos aspectos de la Licencia de know how. Bogotá, Edit. Zadi.

GUISADO TATO, MANUEL (1986). "La evaluación del leasing. Nuevas consideraciones en el contexto de un esquema financiero mixto como alternativa”. En: Alta Dirección. (1986). Julio-agosto de 1986. Barcelona, Bosch.

KENNEDY, DAVID (2002). Rompiendo moldes en el derecho internacional. Buenos Aires, Dykinson.

KOTLER, PHILIP (1996). Dirección de la Mercadotecnia. Octava. Edición. México, Prentice Hall.

LEYVA SAAVEDRA, JOSÉ (1977). El Leasing. Lima, Edit. Unilaw.

(2001). Factoring. Lima, Edit. Legal Boosk's SAC.

. (2004). Contratos de Financiamiento. Lima, Grijley

MAGUIÑA FLORES, RAÚL (2003). La Globalización. Tingo María, Editorial Universidad Nacional Agraria de la Selva.

MARZORATI, OSVALDO (1990). "El contrato de franchising en el Derecho Comparado”. En: COLEGIO DE ABOGADOS. (1990). Revista del Colegio de Abogados. Edición $\mathrm{N}^{\circ} 1$. Buenos Aires.

MASSANGUER, JOSÉ (1989). El contrato de licencia de know how. Barcelona, Librería Bosch.

MEYER, H. Y KOHNS, S. (1992). Acerca de la duración de Franquicias. Primera Edición. Barcelona, Bosch.

MEYER, WARREN G. (1992). Marketing, ventas al por menor. Primera Edición. Lima, Editorial Dike.

ORGANIZACIÓN MUNDIAL DE LA PROPIEDAD INTELECTUAL (1977). Guía de licencias para los países en desarrollo. Madrid, Publicación OMPI. 
PAIVA H., GABRIELA. (1991). Aspectos jurídicos y económicos de la transferencia de tecnología. Santiago de Chile, Editorial Jurídica de Chile.

PORTER, MICHAEL E. (1991). La Ventaja Competitiva de las Naciones. Argentina, Ediciones Vergara.

RAMIS M., POMPEYO (1995). Tecnología y sociedad. Notas suplementarias de apoyo. Mérida, Universidad de los Andes. Facultad de Ciencias Jurídicas y Políticas. Especialización en Propiedad Intelectual. Mérida, Edit. Universidad.

RIBÓ DURÁN, LUIS (1988). Diccionario de Derecho Empresarial. Barcelona, Editorial Bosh SA.

. (1998). Diccionario de Derecho Empresarial. Tomo I, letra N. Barcelona, Editorial Bosh S.A.

ROCA GUILLAMÓN, JUAN (1976). El contrato de factoring y su regulación por el derecho privado español. Madrid, Civitas.

RODRÍGUEZ AZUERO, SERGIO (1990). Contratos Bancarios. Lima, Industria Gráfica.

SÁNCHEZ BUSTILLO, AUGUSTO (2006). El contrato de Factoring, La Banca de Desarrollo y el factoring electrónico. Lima, Editorial San Marcos.

VERA PAREDES, ISAÍAS (2002). Arrendamiento Financiero Operativo .

VILLACORTA, CAVERO ARMANDO (2001). Productos y Servicios Financieros Operaciones Bancarias. Lima, Instituto de Investigación El Pacífico, Pacífico Editores.

\section{Normas Legales}

Código Civil del 14 de noviembre de 1984.

Decreto Legislativo N. ${ }^{\circ} 212$ del 12 de junio de 1981.

Decreto Legislativo N. ${ }^{\circ} 299$ del 26 de julio de 1984.

Decreto Ley N. ${ }^{\circ} 22738$ del 23 de octubre de 1979.

Decreto Supremo N. ${ }^{\circ}$ 559-84-EFC.

\section{Internet}

CABALLERO BUSTAMANTE. "Revista Informativa". En línea: http://www.caballerobustamante. com.pe/boletin/boletincomercial33.asp

. "Revista Informativa". En línea: http:// www.caballerobustamante.com.pe/boletin/ boletincomercial34.asp
LEYVA SAAVEDRA JOSÉ. "El factoring, un negocio de autofinanciamiento". En línea: http://www. injef.com/revista/empresas/factoring2a.htm

TÉLLEZ SÁNCHEZ, LINO; FERRANDO ALONSO, LETICIA; Y PEÑA DOMÍNGUEZ, MISDALIA. "Trabajo sobre el Factoring. Legislación y tratamiento contable". En línea: www.monografias.com/trabajos16/factoring-contable

TRELLES ARAUJO, GUSTAVO. "Publicación sobre el leasing”. En línea: www.gestiopolis.en/www. gestiopolis.com/recursos/documentos/fulldocs/ fin1/elleasing.htm

\section{BIBLIOGRAFÍA COMPLEMENTARIA}

ARCE GARGOLLO, JAVIER (1985). Contratos Mercantiles Atípicos. Primera Edición. México D.F., Editorial Porrúa.

ARIAS-SCHREIBER PEZET, MAX (1998). Exégesis del Código Civil Peruano de 1984. Lima, Gaceta Jurídica.

AROTOMA CACÑAHUARAY, SIXTO (1999). "Factibilidad Operativa de Joint Venture en la Producción y Comercialización de Frijol: Perú". Tesis para optar el Grado de Magíster en Administración, mención Comercio Internacional. Lima, FCA - UPG, UNMSM.

AZUERO RODRÚGUEZ, SERGIO (2005). Contratos bancarios, su significado en América Latina. Bogotá, Editorial Carbajal.

BUCHEL, BETTINA (2002). "La Búsqueda del Equilibrio de la Gestión de Joint Venture”. En: Harvard Deusto Bussiness Review. Marzo del 2002. Bilbao, Editorial Deusto.

OLAIACOVO, JUAN LUIS; ÁVARO, RUBÉN DANIEL y OTROS (1992). Joint Venture y otras formas de cooperación empresaria internacional. Argentina, Ediciones Machi.

CONTRERAS Q., GARCÍA (1979). Transferencia de tecnología a países en desarrollo. Caracas, Instituto Latinoamericano de Ciencias Sociales.

FARINA, JUAN (1993). Contratos Comerciales Modernos. Segunda Edición. Buenos Aires, Editorial Astrea.

FERNÁNDEZ SÁNCHEZ, ESTEBAN (1996). Innovación, Tecnología y Alianzas Estratégicas. España, Editorial Civitas SA. 
GARCÍA L., MARÍA T. (2000). Protección penal del secreto de empresa. Madrid, Editorial Colex.

GORDOBERA DE GARRIDO (1985). Contratos Típicos y Atípicos. Primera Edición. Buenos Aires, Editorial Universidad.

HARRIGAN, KATHRYN RUDIE (1992). Joint Venture - Los Secretos de una Administración Exitosa. Buenos Aires, Editorial Machi.

HUNDSKOPF E., OSWALDO (1994). Derecho Comercial, nuevas orientaciones y temas modernos. Lima, Universidad de Lima.

KOHNS STONE MEYERS, Harris (1992). Marketing, Ventas al por menor. Primera Edición. Bogotá, MacGraw Hill.

LASZLO, ORBAN (1970). Evaluación Financiera de Arrendamiento de equipos, Administración de Empresas. Buenos Aires, Editorial Astrea.

LAURE, MAURICE (1978). "La contribución del Arrendamiento a las Técnicas Financieras. Cómo se práctica en Francia”. En: Revista Bancaria. México D.F., Editorial Alfa Omega.

LAVALLE COBO, JORGE (1992). Leasing Mobiliario. Buenos Aires, Edit. Astrea.

LEYVA SAAVEDRA, JOSÉ. (2004). Contratos de Financiamiento. Lima, Grijley EIRL. (1995). Leasing. Lima, Edit. Grijley.
LINARES BRETÓN, SAMUEL (1978) "El Contrato de Locación Financiera (Leasing) en la Banca Argentina”. En: Revista FELABAN. Septiembre de 1978. Bogotá, Ediciones Kora.

LÓPEZ DE SA, A. (1972). Leasing e Financas de Empresas. Río de Janeiro, APEC Editora SA.

MALCA GUAYLUPO, OSCAR (1995). "Los Joint Venture y la Promoción de Exportaciones”. En: ADEX. (1995). Revista Perú Exporta. № 224. Abril de 1995. Lima, Grupo Imagen.

MARZORATI, OSVALDO J. (1996). Alianzas Estratégicas y Joint Venture. Argentina, Editorial Astrea.

MIQUEL RODRÍGUEZ, JORGE (1998). La Sociedad Conjunta (Joint Venture Corporación). España, Editorial Civitas SA.

MIRANDA ALCÁNTARA L, MANUEL IVÁN (2003). "El Joint Venture en la Ley General de Sociedades". En: Revista Jurídica del Perú. Año LIII, N. ${ }^{\circ}$ 50. Septiembre del 2003. Lima, Fimart SAC Editores.

SORIO RUIZ, ZAIDA (1999). Contratos Comerciales y Empresariales. Primera Edición. Lima, Ediciones Legales Iberoamericana EIRL.

SIERRA ALTA, ANÍBAL (1997). Joint Venture Internacional. Segunda Edición. Lima, Editorial Pontificia Universidad Católica del Perú. 